\title{
Exploring Molecular Insights of Cereal Peptidic Antioxidants in Metabolic Syndrome Prevention
}

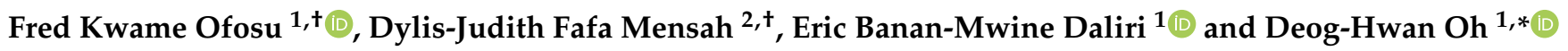 \\ 1 Department of Food Science and Biotechnology, College of Agriculture and Life Sciences, \\ Kangwon National University, Chuncheon 24341, Gangwon-do, Korea; ofosufk17@kangwon.ac.kr (F.K.O.); \\ ericdaliri@yahoo.com (E.B.-M.D.) \\ 2 Department of Family and Consumer Sciences, College of Applied Science and Technology, \\ Illinois State University, Normal, IL 61761, USA; dylisjudithmensah@gmail.com \\ * Correspondence: deoghwa@kangwon.ac.kr; Tel.: +82-33-250-6457; Fax: +82-33-259-5565 \\ + These authors contributed equally to this work.
}

Citation: Ofosu, F.K.; Mensah, D.-J.F.; Daliri, E.B.-M.; Oh, D.-H. Exploring Molecular Insights of Cereal Peptidic Antioxidants in Metabolic Syndrome Prevention. Antioxidants 2021, 10, 518 https://doi.org/10.3390/antiox10040518

Academic Editors: Soichiro

Nakamura, Shigeru Katayama and Henry M. Corpuz

Received: 26 February 2021

Accepted: 20 March 2021

Published: 26 March 2021

Publisher's Note: MDPI stays neutral with regard to jurisdictional claims in published maps and institutional affiliations.

Copyright: (c) 2021 by the authors. Licensee MDPI, Basel, Switzerland. This article is an open access article distributed under the terms and conditions of the Creative Commons Attribution (CC BY) license (https:// creativecommons.org/licenses/by/ $4.0 /)$.

\begin{abstract}
The prevalence of metabolic syndrome (MetS) is presently an alarming public health problem globally. Oxidative stress has been postulated to be strongly correlated with MetS, such as type 2 diabetes, obesity, hypertension, cardiovascular diseases, and certain cancers. Cereals are important staple foods which account for a huge proportion of the human diet. However, owing to recent growing demand and the search for natural antioxidants for the prevention and management of MetS, cereal peptides have gained increasing attention for developing functional ingredients or foods with substantial antioxidant properties. This review explores the current production techniques for cereal peptidic antioxidants and their potential mechanism of action in the prevention and management of MetS.
\end{abstract}

Keywords: cereal grains; antioxidant peptides; oxidative stress; metabolic syndrome; functional food

\section{Oxidative Stress}

The term "oxidative stress" was initially conceptualized about three (3) decades ago [1,2]. Since then, the term has evolved remarkably. The inception of oxidative stress finds its roots in early publications of Seyle (loc. cit), which were concerned with the toxicity of oxygen linked with aging, bodily responses and processes associated with oxygen radicals, the concept of the physiology of the mitochondria and research on its aging, as well as work on variances of redox reactions in living organisms [1]. Table 1 shows several definitions proposed by different scientists over the years. Consequently, oxidative stress is denoted by an imbalance between oxidant and antioxidant species, such that oxidant species weigh more, which results in the excessive release of free radicals or reactive oxygen species (ROS) and causes cellular and molecular disruption, as well as a negative influence on redox signaling [3-5]. Oxidative stress occurs when antioxidant defenses are impaired or are not strong enough to overpower the production of reactive oxygen species (ROS) $[3,4,6]$. The consequences of oxidative stress may be progressive and often dire. The two underlying components in oxidative stress, as evidenced by the definition above, are prooxidant and antioxidant species. It is their non-homeostatic co-existence that results in oxidative stress. To prevent excess ROS production in mammalian cells, antioxidant molecules and antioxidant enzymes act as defense systems. There are many prooxidant species and antioxidant species. In cells, glutathione (GSH) is the most abundant and important non-protein antioxidant molecule. Antioxidants are those substances that counteract the harmful effects of oxidants. They are usually produced in insufficient quantities by the body; therefore, they need to be supplemented frequently from external sources, typically food sources [7]. Examples of antioxidants are vitamins A, C, E, carotenoids (including beta-carotene and astaxanthins), and polyphenols (such as flavonoids, isoflavones, anthocyanins, chlorogenic, and catechins) [7-9]. Examples of prooxidants, particularly the reactive species, 
include reactive oxygen species (ROS) [6,10], reactive sulfur species (RSS) [11], reactive electrophile species (RES) [12], reactive carbonyl species (RCS) [13,14], reactive nitrogen species (RNS) [15-17], and reactive halogen species (RHS) $[10,15,18]$. ROS, RHS, and RNS are toxic oxidants that cause damage to DNA, RNA, lipids, and phagocytosed pathogen proteins, especially during inflammation [10]. According to Yang et al. [19], ROS, RHS, and RNS cause apoptosis by directly oxidizing protein, lipid, and DNA signaling pathways, which increases the risk of CVD, specifically atherosclerosis. RSS are molecules produced from sequential one-electron oxidations (loss of electrons in a chemical reaction) of hydrogen sulfide, thus forming thiyl, hydrogen persulfide, and the persulfide "supersulfide" radicals, before terminating in elemental sulfur [11]. There are resemblances between ROS and RSS, and they are sometimes misconstrued and used interchangeably. However, RSS have more effectiveness, reactivity, signaling, and versatility potential compared to ROS. They can also be accumulated and reused [11]. RES have a wide range of functionality with overlying chemical reactivity, which sometimes makes the study of biological RES challenging. Biologically, they range in different shapes and forms. RES involved in cell signaling may even rise higher when they sense the human body is stressed. RHS control antioxidant response, cell growth, DNA damage development, aging, cellular homeostasis events, such as apoptosis, and immune response [12].

The oxidation of macromolecules, such as carbohydrates, lipids, and amino acids, produces many reactive carbonyl species (RCS). RCS can react and cause changes to the surface composition of proteins, nucleic acids and amino phospholipids, and therefore serve as agents of cell destruction and gene mutation. Furthermore, interaction of RCS with biological samples results in many chemical products that have diverse negative effects on human health [13]. RCS are shown to be involved in ROS signaling, and are typically classified under RES [14]. Electrophilic and nucleophilic reactions are some of the most common covalent bond formations that are found in many chemical-cellular reactions. The electrophilic nature of carbonyl compounds has a high affinity for nucleophilic cellular constituents, thus making it possible for easy accessibility of the cells by RCS to render its physiological effects $[13,14]$. In the form of free radicals, such as nitric oxide and other nitric oxide-derived species (organic species, such as 3-nitrotyrosine (3-NT) and S-nitrosothiols (RS-NO), and inorganic species, such as nitrite [15]), RNS are involved in a variety of biological activities, and their detection and quantification are technically difficult $[15,16]$. However, there is evidence that, when RNS is produced in excess, it disrupts protein synthesis in the body, which harms mitochondrial metabolism dynamics and mitophagy in the nervous system [17]. RHS, especially those with chlorine, bromine, and iodine (thus, $\mathrm{HOX}$ with $\mathrm{X}=\mathrm{Cl}$, Br or I) induce injuries to DNA, RNA, lipids, and proteins cells $[10,15]$. They render the immune system's defense useless when they are released into the body in high quantities by reversing the action of phagocytes (including neutrophils, monocytes, macrophages, mast cells, dendritic cells, osteoclasts, and eosinophils) that capture pathogens, and, thus, instigate disease or infection pathogenesis [10]. When RHS interreact with extracellular myeloperoxidase (MPO) produced by neutrophils to provide immune system defenses against pathogens, it results in tissue damage, cellular damage, and inflammatory reactions that facilitate the occurrence of a variety of diseases, particularly CVD (atherosclerosis), obesity, T2DM, and, ultimately, metabolic syndrome (MetS) $[10,18]$. Owing to the vast quantities and differences in prooxidant and antioxidant species, the best way to understand oxidative stress is through a classification system. According to Sies et al. [4], oxidative stress can be classified according to its intensity (basal, low, intermediate, and high), specific forms, related terms, and associated biological responses (Figure 1). A further assessment by Lushchak [20] establishes that imbalance could also result from one or a combination of the following: elevated levels of endogenous and exogenous compounds entering autoxidation, coupled with ROS production; depleted stores of low molecular mass antioxidants; deactivated antioxidant enzymes; and reduced production of antioxidant enzymes and low molecular mass antioxidants. These determine the three types of oxidative stress—acute, chronic, and quasi-stationery [20-23] (Table 2). 


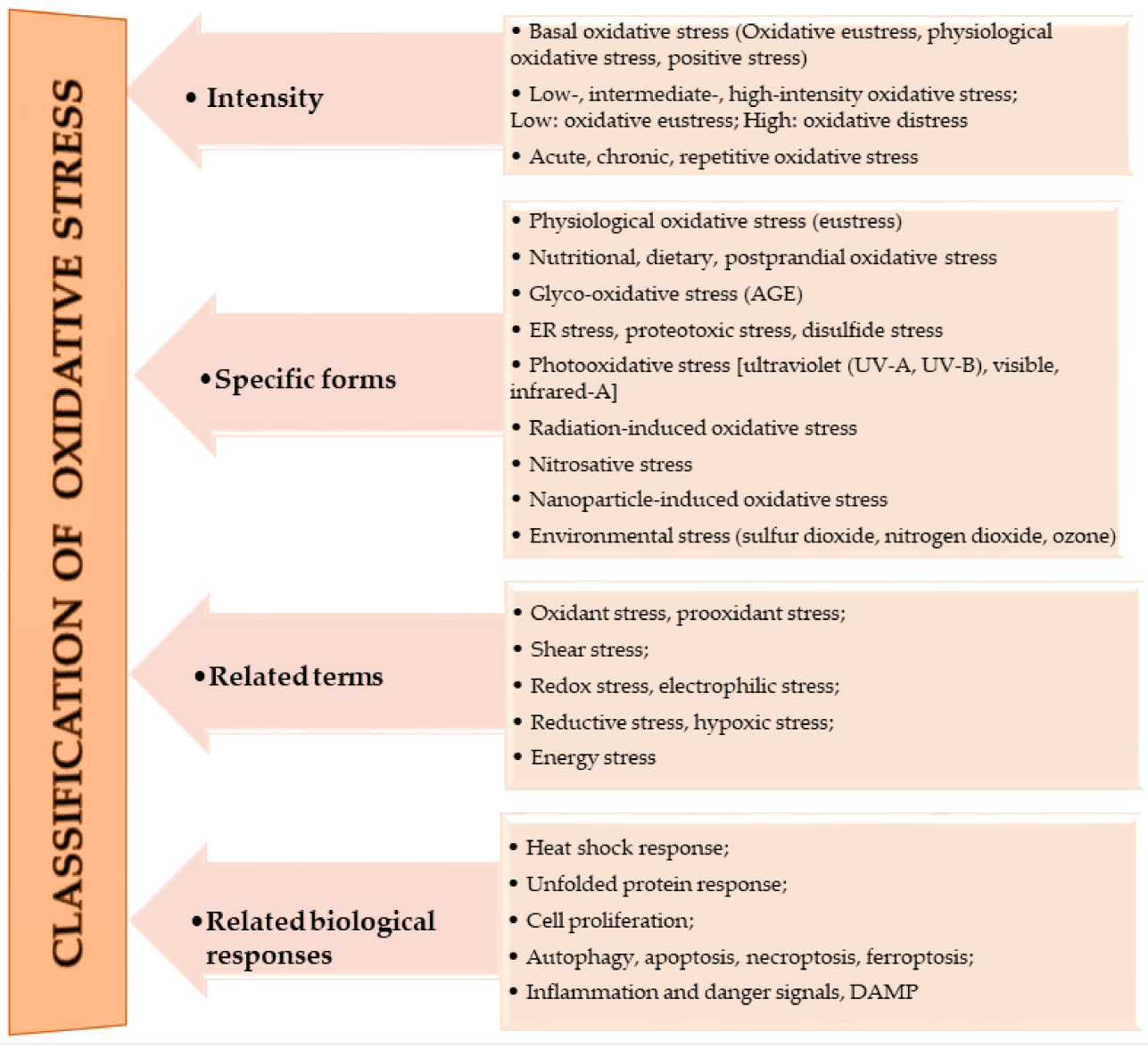

Figure 1. Classifications of oxidative stress adapted with permission from Sies et al. [4]. Copyright 2017 Annual Reviews, Inc.

Table 1. Some proposed definitions of oxidative stress throughout the course of time.

Definition of Oxidative Stress
\begin{tabular}{c}
\hline Reference \\
Oxidative stress is a disturbance in the prooxidant-antioxidant balance in \\
favor of the former.
\end{tabular}
$\begin{gathered}\text { Oxidative stress is defined as a disturbance in the prooxidant-antioxidant } \\
\text { balance that leads to potential damage. }\end{gathered}$
Oxidative stress is a situation when steady-state ROS concentration is
transiently or chronically enhanced, disturbing cellular metabolism, its
regulation, and damaging cellular constituents.
Oxidative stress is defined as excess production of reactive oxygen species
(ROS) relative to antioxidant defense.


Table 2. Types/Levels of oxidative stress.

\begin{tabular}{ccc}
\hline Oxidative Stress & Definition & Reference \\
\hline Acute & $\begin{array}{c}\text { The inability of cells to neutralize enhanced ROS level } \\
\text { over a period of time, such that the time is enough to } \\
\text { result in specific physiological consequences. } \\
\text { It occurs when acute oxidative stress progresses to } \\
\text { significantly disturb homeostasis. Here, the ROS levels are } \\
\text { elevated and very stable, and very potent in altering } \\
\text { healthy cell components. }\end{array}$ & {$[20-23]$} \\
Quasi-stationery & $\begin{array}{c}\text { It occurs when ROS levels are so elevated that it is almost } \\
\text { impossible to return to ideal homeostatic levels, thus } \\
\text { resulting in the need for a substantial reorganization of } \\
\text { the entire homeostatic system. }\end{array}$ & {$[22,23]$} \\
\hline
\end{tabular}

\section{Metabolic Syndrome (MetS)}

Insulin resistant syndrome, MetS, or dysmetabolic syndrome are other terms used to denote metabolic syndrome. MetS is a health condition characterized by the summative complexities of three or more of the following risk factors: high blood pressure, abdominal obesity, elevated triglyceride (TG) levels, low high-density lipoprotein (HDL) levels, and high fasting levels of blood sugar that instigate the potential for cardiovascular diseases (CVDs) and type 2 diabetes mellitus (T2DM) [28-30]. Typically, low high-density lipoprotein (HDL) levels are less than $40 \mathrm{mg} / \mathrm{dL}$ in men, or less than $50 \mathrm{mg} / \mathrm{dL}$ in women; elevated TG is $150 \mathrm{mg} / \mathrm{dL}$ of blood or higher; elevated fasting glucose is $100 \mathrm{mg} / \mathrm{dL}$ or higher; and high blood pressure is indicated by systolic levels of $130 \mathrm{mmHg}$ or higher and/or diastolic levels of $85 \mathrm{mmHg}$ or higher [31]. Research purports a positive correlation between increases in age and obesity, and the prevalence of MetS [32,33]. Sigit et al. [34] argue that MetS is sex and population specific. Current trends suggest Asian populations are showing, relatively, the highest prevalence (an estimate of $39.9 \pm 0.7 \%$ ) [34,35]; about one-third of US adults (thus, $34.3 \pm 0.8 \%$ of all adults and $50 \%$ of those aged 60 years or older) have MetS [33,36]; and about $29.2 \pm 0.7 \%$ in European populations [34-36]. Comparatively, the prevalence is very minimal in populations in Africa; however, diabetes, one of the pre-indicators of MetS, is expected to have huge spikes in sub-Saharan Africa, the Middle East, and North Africa (141\% and 104\%, respectively) in the next 25 years [30]. It is worth noting that sex and populations showed differing prevalence and contributing risk factors of MetS. For instance, in relation to sex, the incidence of MetS was higher in Indonesian women than in Indonesian men, but higher in Dutch men than in Dutch women [34]; in relation to contributing risk factors, Asian-Chinese men recorded higher TG and FBS levels than European men. Again, Chinese women recorded higher glucose levels than European women [34,37]; abdominal obesity was higher in Dutch women than in Indonesian women [34].

\section{The Link: Oxidative Stress and Metabolic Syndrome}

There is compelling evidence of the association between oxidative stress and MetS from both human and animal studies [38-41]. Oxidative stress correlates with increased BMI, increased adiposity, and high blood pressure, which are all components of the risk factors of MetS. Particularly in obesity-related MetS, elevated ROS production targets adipose tissue and rapidly incites fat accumulation, thereby contributing to atherosclerosis, among other vascular medical conditions [40-42]. Oxidative stress reduces the number of helpful proteins, such as adiponectin (involved in regulating glucose levels and fatty acid breakdown); as adiponectin decreases, systemic oxidative stress levels increase. Oxidative stress associated with increased adiposity mediates the development of MetS [38,42,43]. There are two main mechanisms by which this occurs: first, through increased oxidative stress in accumulated fat, resulting in uncontrolled adipocytokines production; and second, the selective rise in reactive species production in accumulated fat, resulting in high systemic oxidative stress [38-41]. Oxidative stress impairs pancreatic beta cells' ability 
to secrete insulin, affecting glucose transport in muscle and adipocytes which relates to the development of hypertension and diabetes [38,42]. The association between oxidative stress and MetS is shown in Figure 2.

\section{Oxidative Stress}

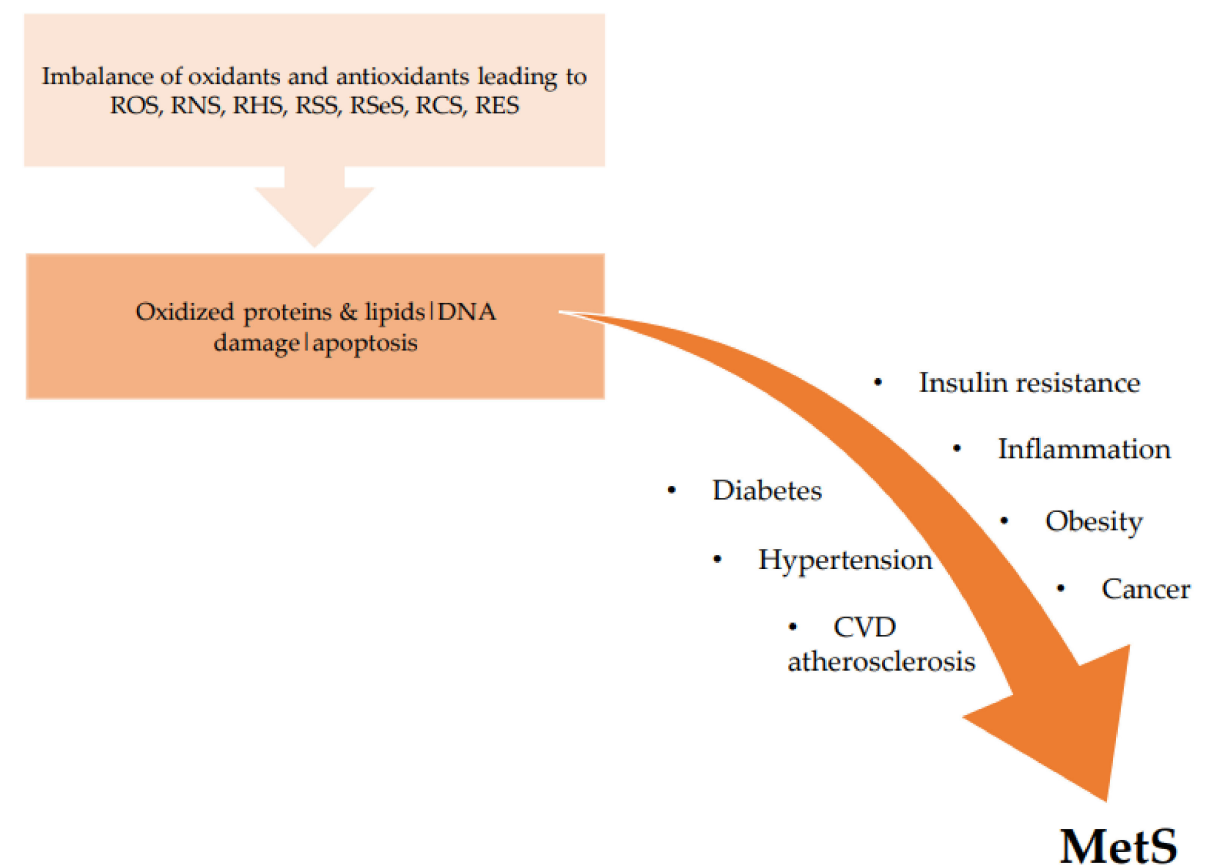

Figure 2. Association between oxidative stress and MetS. ROS: reactive oxygen species; RNS: reactive nitrogen species; RHS: reactive halogen species; RSS: reactive sulfur species; RSeS: reactive selenium species; RCS: reactive carbonyl species; RES: reactive electrophile species; CVD: cardiovascular diseases.

\section{Antioxidative Peptides}

Bioactive peptides (BP) are short protein fragments obtained from food proteins that can provide beneficial effects to the human body system due to their unique healthpromoting properties [44]. BP differ from protein by their small molecular weight, formed by short sequences of amino acids that are linked together by amide or peptide bonds [45]. BP usually contain between 3 and 20 amino acid residues, and remain inactive while the sequences are kept within the parent protein. They are activated by the peptidases that incite enzymatic hydrolysis during food processing and/or during gastrointestinal (GI) digestion [46]. During digestion, BP must cross the gastrointestinal barrier and survive enzyme degradation in order to have a positive health effect [47]. Depending on the sequence of the amino acid sequence, BP render many functional, physiological, and therapeutic properties, including antihypertensive [48], antioxidant [48,49], anti-obesity [50], antifungal, antiviral, immunomodulatory [51], antimicrobial [51,52], anticoagulant [53], anti-inflammatory [54], antidiabetic, iron- and calcium-binding activities [55], antiproliferative [56] and chelating effects [57]. They also account for the taste of food and the inhibition of enzymes involved in developing diseases. Functional foods obtained from animal and plant sources have been shown to contain high-value BP with primarily antioxidant properties. A few examples of these animal and plant sources of BP include seafood [58,59], egg [55], goat milk [60], bovine [61], rice bran [62], soybean [63] and cauliflower byproducts [64].

While still emerging, the applications of food-derived antioxidants are varied and diverse. There is evidence of their utilization in food systems [65], nutrition and nutraceuticals, additive development, therapeutics [66], and food preservation [67]. In animal-derived antioxidant peptides, such as in milk, they have been used successfully as free radical scavengers [68]. Plant-derived antioxidants are used for taste enhancement and as health fortification agents [69], such as liver protectants [70], memory enhancers [71], and supple- 
ments to promote healthy cells [72,73]. In therapeutics, plant-derived antioxidant peptides are effective in treating blood disorders [74], hypertension [75,76] and malaria [77,78]. Among the plants' sources, cereals have been extensively studied and found to exert substantial antioxidant potential to alleviate oxidative stress. Cereals account for a huge proportion of the human diet, and the presence of mono- or multifunctional peptides contributes to an increase in their food protein quality for daily consumption [79]. The amino acid composition, sequence and molecular weight are key factors that contribute to the antioxidant activities of peptides [80].

\section{Cereals Historical Significance and Assortments}

History has it that the word "cereals" is traced to Ceres, the Roman goddess who symbolizes the power to produce food-agriculture and cultivation, fertility, abundance, and nurturance. In fact, ancient Romans are credited for a sculpture of Ceres which sits on the arch of the Chicago Board of Trade assembling - a significant place for agricultural products' marketing. The old Romans are generally recognized as the pioneers of the cereal industry. They were the first to introduce cereal processing (thus, crushing of grain and utilizing flour to make refined white bread) [81]. Cereals refer to an edible seed of the grass which comprises a germ (the innermost core, rich in fats and vitamins), the endosperm (the middle layer, rich in carbohydrates and some traces of protein and vitamins), which is housed by bran (the outermost layer of fiber and B-vitamins) [82]. They serve as highly dense carbohydrate foods for many populations worldwide [83,84]. They are edible seeds from members of the grass family Gramineae or Poaccac [49]. They are also referred to as grains; however, grains compose both the fruit (kernel or seed) and the grass [81]. Maize, wheat, barley, rice, oat, millet, sorghum, and rye are amongst the most famous types of cereals; however, wheat takes the lead globally [49]. Although the cereals mentioned above belong to the same family, they each have a unique genus, as shown in Table 3.

Table 3. Major assortments of cereals-specific genus.

\begin{tabular}{cccccc}
\hline Cereal & Family & Sub-Family & Tribe & Genus & Reference \\
\hline Wheat & & Pooideae Bentham & Triticeae & Triticale & {$[49,56]$} \\
Rye & & Pooideae Bentham & Triticinae & Triticale & {$[49,56]$} \\
Barley & & Pooideae Bentham & Hordeinae & Triticale & {$[49,56]$} \\
Oat & Gramineae or & Pooideae Bentham & Aveneae & Aveneae & {$[56]$} \\
Millet & Poaccac & Panicoideae Link & Paniceae & Panicease & {$[49]$} \\
Sorghum & & Panicoideae Link & Andropogoneae & Sorghum & {$[49]$} \\
Maize & & Panicoideae Link & Maydeae & Zea & {$[49,56]$} \\
Rice & & Ehrhartoideae Link & Oryzeae & Oryza & {$[49,56]$} \\
\hline
\end{tabular}

\subsection{Cereals as Sources of Antioxidant Peptides}

\subsubsection{Oats}

Oats contain prolamins known as avenins [82]. There are two types of bioactive peptide properties in oats-antioxidant and anti-inflammatory. High potent antioxidants are typically associated with peptides containing 2-20 amino acids with a molecular weight of less than $3 \mathrm{kDa}$, and with the presence of hydrophobic amino acids, such as proline $(\mathrm{P})$, valine $(\mathrm{V})$, tryptophan $(\mathrm{W})$, and phenylalanine $(\mathrm{F})$. Amino acids, such as valine $(\mathrm{V})$ and leucine (L), have also been reported to provide antioxidant properties when found at the N-terminal of a peptide. Oats are rich in avenanthramide, a polyphenol whose components are characterized by a pseudo-peptide bond known to possess both antioxidant and anti-inflammatory activities [85]. Avenanthramides decrease inflammation-related cytokine production by inhibiting specific nuclear factor activities. Certain species of oats have special anti-inflammatory potency towards autoimmune diseases, such as celiac disease [56]. Oats have a high oxygen radical absorbance capacity, (ORAC) related to the elevation in antioxidant enzymes' action, and significantly decrease the occurrence of oxidative stress and other harmful specific nuclear factor activity protein levels. 


\subsubsection{Wheat}

Gluten in wheat incites inflammation responses among some minute allergen-stricken populations, particularly those with celiac [86,87]. Prolamins in wheat are called gliadins [82]. Wheat antioxidant peptides reduce the occurrence of tumor necrosis $[56,88]$. Several peptides or protein hydrolysates, with antioxidative properties obtained from wheat bran, germ and gluten, are shown in Tables 4-7.

\subsubsection{Rice}

Rice has various benefits, right from the germ through to its outermost layer (bran), which is usually lost through the series of food processing [62]. Rice bran is rich in albumin hydrolases, which are potent for combating hypertension, diabetes, and oxidation in cells through antioxidant and $\alpha$-glucosidase, as well as angiotensin-converting enzyme (ACE)inhibitory activities [62,89]. Antioxidants and anti-inflammatory properties, mainly in black rice, have been linked to the lowering of inflammation markers, such as high-sensitive C-reactive proteins (CRP) and risks of cardiovascular diseases (specifically, coronary heart disease and atherosclerosis) $[56,62,89]$. Examples of different rice peptides and protein hydrolysates demonstrating potent antioxidant activities are shown in Tables 4-7.

\subsubsection{Barley}

Barley is a crop used for humans and livestock, and has recently drawn attention as a medicinal grain. Prolamins constitute $30-50 \%$ of barley's total proteins and are called hordeins $[49,82]$. Research studies over the past decade have shown the biological activities of barley [56]. Flavourzyme and alcalase hordein hydrolysates exhibited superior DPPH free radical scavenging activity $(70 \%)$ at $0.5 \mathrm{mg} / \mathrm{mL}, \mathrm{Fe}^{2+}$-chelating ability $(73 \%)$ at $1 \mathrm{mg} / \mathrm{mL}$, and superoxide radical scavenging capacity [90]. The potential of barley to function as an anti-inflammatory and antioxidant has been tested in both human and animal studies. In the beverage industry, where indignant alcohol consumption has been positively correlated to induce excessive production of ROS, resulting in liver damage, fermented barley is a healthier choice. Fermented barley extracts are linked to improving antioxidant activities by assuaging alanine aminotransferase and aspartate aminotransferase levels [56,91,92]. Additionally, fermented barley extracts were shown to suppress IL-1, IL-6, and tumor necrosis factors in lipopolysaccharide (LPS)-induced inflammation in rats, thus reiterating the anti-inflammatory activities of barley extracts [91]. The fundamental principle of the anti-inflammatory effects of fermented barley extracts was related to the upregulation of antioxidant enzyme activities and the downregulation of oxidative stress. From the aforementioned, it is evident barley has potential benefits in fighting inflammation-related diseases [56,92].

\subsubsection{Rye}

Rye is typically considered one of the minor grains. Prolamins, the major storage proteins in rye, are referred to as secalins $[49,82,85]$. Rye resembles wheat and barley, and is predominantly cultivated in Europe. Rye is famous for food products, such as whiskey and bread [56]. Four tripeptides (CQV, QCA, QCV and QVC) derived from rye secalin demonstrated hydroxyl radical scavenging and chromium-VI $(\mathrm{Cr}(\mathrm{VI})$ reducing activities [93]. Rye sourdough fermentation with lactic acid bacteria resulted in the synthesis of antioxidant peptides PAEMVAAALDR, KVALMSAGSMH, LCPVHRAADL, and RLSLPAGAPVTVAVSP. These peptides showed high DPPH radical scavenging activity, linoleic acid autoxidation inhibition, and cytoprotection on $\mathrm{H}_{2} \mathrm{O}_{2}$-induced mouse fibroblasts oxidative damage [94].

\subsubsection{Maize}

Like all cereals, maize (also known as corn) seed basically consists of an embryo, an endosperm, and bran; the starch grains are found in the endosperm (which contains mostly amylopectin and amylose, followed by proteins) [83]. The most abundant proteins are 
albumins, globulins, prolamins, and glutelins found in endosperm and germ, with glutamic acid being the most abundant amino acid [95]. Maize has been found to provide bioactive peptides that are essential for nutraceutical functions [72]. The enzymatic hydrolysis of the maize kernel produces various bioactive peptides found in maize. Recently, OrtizMartinez et al. [82] reported on the anticancer effects of corn peptides in HepG2 cells. In other words, some maize bioactive peptides have shown profound antioxidative effects by the presence of specific amino acids, such as proline $(\mathrm{P})$, tyrosine $(\mathrm{Y})$, histidine $(\mathrm{H})$, phenylalanine $(\mathrm{F})$, lysine $(\mathrm{K})$, and histidine $(\mathrm{H})$, that are very strong in reducing ROS [96]. Tang and Zhuang [95] found low molecular weight peptides (less than $5 \mathrm{kDa}$ ) to be powerful antioxidants. These small peptides showed hydroxyl radical and free radical scavenging activity, inhibition of lipid peroxidation, and ion chelating capacity properties. In corn gluten meal, CSQAPLA demonstrated antioxidative activities by scavenging superoxide anion and hydroxyl radicals [72,96]. Some examples of corn antioxidant peptides are shown in Tables 4-7.

\subsubsection{Millet}

Millets, numerous small seeds, are cultivated in warm countries as cereal crops or grains, and are used to produce flour and alcoholic drinks for fodder and human consumption. Millets are classified into major and minor types. The major type includes pearl millet (pennisetum glaucum), proso, or white millet (panicum miliaceum), foxtail millet (setaria italic), and finger millet (eleusine coracana) [97]. Whereas, barnyard millet (echinochloa spp.), little millet (panicum sumatrense), guinea millet (brachiaria deflexa), browntop millet (urochloa ramose), kodo millet (paspalum scrobiculatum), and sorghum (sorghum spp.) constitute minor millets [98]. A typical millet protein has been shown to contain albumin, globulin, cross-linked prolamins and glutelin, and some essential amino acids, such as cysteine (C) and methionine (M) [99]. Recently, the use of millet as nutraceuticals and therapeutic agents is on the rise because of its high content of health-promoting BP, which have promising antioxidants, anti-inflammatory, antihypertensive, antidiabetic, and anticancer effects [97]. Hu et al. [100] reportedly identified seven peptides from foxtail millets (predominantly EDDQMDPMAK and QNWDFCEAWEPCF) with high anti-inflammatory properties responsible for reducing ROS activity and increasing levels of glutathione and superoxide dismutase activity in Caco-2 cells. Recently, identified peptide sequences VAITLTMK and VSKSVLVK, from lower millets, and TSSSLNM, VRGGLTR and STTVGLGISMRSASVR, from finger millets, demonstrated strong antioxidative properties [101,102].

\subsubsection{Sorghum}

Globally, sorghum ranks as the fifth most cultivated cereal [103]. Due to its high adaptability to high temperatures and drought, sorghum is very commonly cultivated in many suburbs of Africa, Asia, and other semi-desert climate areas of the world [102,104,105]. Sorghum is gluten-free. $\alpha$-kafirin is the main storage protein in sorghum [104]. However, proteins in sorghum are relatively lower in quality compared to other cereals [103]. A study by Agrawal et al. [102] on green tender sorghum varieties concluded that hydrolyzed proteins in sorghum resulted in significant antioxidant performance by scavenging DPPH, 2,2'-azinobis-3-ethyl-benzothiazoline-6-sulphonate (ABTS) radicals and promoting metal chelating, and could be applied in the development of nutraceuticals. Though studies are still emerging on the health benefits specific to antioxidative peptides, many varieties of sorghum are reported to be rich in 3-deoxyanthocyanidins, tannins, and polycosanols, which are effective in solidifying gut microbiota roles against obesity, dyslipidemia, oxidative stress, inflammation, diabetes, hypertension, and some types of cancers $[102,104,106,107]$. Needless to say, these are potentially anti-inflammatory, cholesterol-lowering, antioxidant characteristics typically evident in BP. Tables 4-6 shows examples of sorghum and millet antioxidant peptides. 
Table 4. Chemical assay showing some examples of cereal antioxidant peptides.

\begin{tabular}{|c|c|c|c|c|c|}
\hline Protein Source & Enzyme & Peptide Sequence/Hydrolysate & Size & Assay Outcome & Reference \\
\hline Wheat bran & Alcalase & $\begin{array}{l}\mathrm{NL}, \mathrm{QL}, \mathrm{FL}, \mathrm{HAL}, \mathrm{AAVL}, \mathrm{AKTVF}, \\
\text { and TPLTR }\end{array}$ & $<1,1-10 \mathrm{kDa}$, (membrane ultrafiltration) & Higher ORAC by <1 kDa fraction. & [108] \\
\hline Wheat bran & $\begin{array}{l}\text { Alcalase, favourzyme, papain, } \\
\text { neutral enzyme, trypsin }\end{array}$ & CGFPGHC, QAC, RNF, SSC, WF & $\begin{array}{l}<1 \mathrm{kDa} \text {, (size-exclusion and and } \\
\text { ion-exchange chromatography) }\end{array}$ & $\begin{array}{l}\text { QAC and SSC from alcalase hydrolysate showed } \\
\text { the highest superoxide anion radical scavenging } \\
\text { and Trolox equivalent antioxidant capacity. }\end{array}$ & [109] \\
\hline Wheat germ & Alcalase, pepsin or proteinase $\mathrm{K}$ & $\begin{array}{l}\text { KELPPSDADW, SGGSYADELVSTAK, } \\
\text { GNPIPREPGQVPAY }\end{array}$ & $<2.5 \mathrm{kDa},(\mathrm{RP}-\mathrm{HPLC})$ & $\begin{array}{l}\text { Pepsin fraction showed the strongest ABTS and } \\
\text { DPPH radical scavenging activity. }\end{array}$ & [110] \\
\hline Wheat gluten & Pepsin & LQPGQGQQG, AQIPQQ & $\begin{array}{c}<5 \mathrm{kDa} \text {, (ion-exchange and gel filtration } \\
\text { chromatography) }\end{array}$ & $\begin{array}{l}\text { Fraction } 3 \text { showed stronger antioxidant activity } \\
\text { using ferric thiocyanate method. }\end{array}$ & [111] \\
\hline Wheat gluten & Alcalase & Hydrolysate & Not determined & $\begin{array}{l}\text { Heat and alcalase treated hydrolysate } \\
\text { synergistically increased DPPH and ABTS radical } \\
\text { scavenging inhibition. }\end{array}$ & [113] \\
\hline Rice bran & $\begin{array}{l}\text { Alcalase, Trypsin, } \\
\text { Protamex, Flavourzyme }\end{array}$ & Hydrolysate & N.R & $\begin{array}{l}\text { Flavourzyme hydrolysate exhibited the strongest } \\
\text { DPPH, ABTS radical scavenging and metal } \\
\text { chelating activity. }\end{array}$ & [114] \\
\hline Rice bran & Trypsin & YSK & $<1 \mathrm{kDa}$, (gel filtration, RP-HPLC) & $\begin{array}{l}\text { F2-a fraction displayed strong DPPH radical } \\
\text { scavenging and reducing power activity }\end{array}$ & [115] \\
\hline Brown rice & Bromelain & $\begin{array}{c}\text { GSGVGGAK, SSVGGGSAG, } \\
\text { FGGSGGPGG, FGGGGAGAGG, } \\
\text { GGGGGAAAAGA, } \\
\text { AGGGGGGVVAG, SGPSGGGGAL, } \\
\text { ESDVVSDL }\end{array}$ & $<1 \mathrm{kDa}$, (ultra, gel filtration, RP-HPLC) & $\begin{array}{l}\text { DPPH, ABTS, and hydroxyl radical-scavenging } \\
\text { activities was higher in F4 fraction. }\end{array}$ & [69] \\
\hline Brown rice & Bromelain & $\begin{array}{c}\text { SPFWNINAHS, MPVDVIANAYR, } \\
\text { VVYFDQTQAQA, } \\
\text { AVYVYDVNNNANQ, } \\
\text { YNILSGFDTEL, EFFDVSNELFQ }\end{array}$ & $<1.5 \mathrm{kDa}$, (ultra, gel filtration, RP-HPLC) & $\begin{array}{l}\text { F4 fraction of glutelin hydrolysates showed the } \\
\text { highest ABTS radical scavenging and } \mathrm{Cu}^{2+} \\
\text { chelating activity. }\end{array}$ & [116] \\
\hline Rice bran & Pepsin, Trypsin & 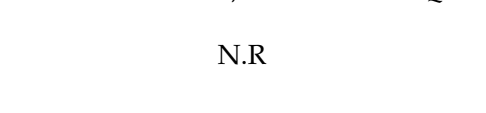 & 3-10 kDa, (ultra, gel filtration, RP-HPLC) & $\begin{array}{l}\text { F2 sub-fraction displayed the highest DPPH, } \\
\text { ABTS radical scavenging and } \mathrm{Fe}^{2+} \\
\text { chelating activity. }\end{array}$ & [117] \\
\hline White and colored rice & Alcalase, Flavourzyme, Neutrase & Hydrolysate & $<10 \mathrm{kDa}$ & $\begin{array}{l}\text { Alcalase hydrolysate of immature rice showed the } \\
\text { highest DPPH and } \mathrm{Fe}^{2+} \text { chelating activity } \\
\text { compared to matured rice. }\end{array}$ & [118] \\
\hline Rice & Pepsin-Pancreatin & Hydrolysate & N.R & $\begin{array}{l}\text { Methionine-supplemented hydrolysates showed } \\
\text { enhanced scavenging capacities for ABTS, } \\
\text { superoxide, and nitric oxide. }\end{array}$ & [119] \\
\hline Rice bran & pepsin-trypsin & N.R & $<3 \mathrm{kDa}$, ultrafiltration & $\begin{array}{l}\text { Higher ABTS radical scavenging and metal } \\
\text { chelating activities in F1 fragment. } \\
\text { Alcalase hydrolysate showed higher DPPH and }\end{array}$ & [120] \\
\hline Rice & Alcalase, Flavourzyme & Hydrolysate & $<3 \mathrm{kDa}$ & $\begin{array}{l}\text { FRAP activities and, hence, improved oxidative } \\
\text { stability of linseed oil during storage. }\end{array}$ & [121] \\
\hline
\end{tabular}


Table 4. Cont.

\begin{tabular}{|c|c|c|c|c|c|}
\hline Protein Source & Enzyme & Peptide Sequence/Hydrolysate & Size & Assay Outcome & Reference \\
\hline Rice & $\begin{array}{c}\text { Microbial proteases } \\
\text { (Validase }^{\circledR}, \text { Neutral Protease, alkaline } \\
\text { protease). }\end{array}$ & Hydrolysate & $1-3 \mathrm{kDa}$, ultrafiltration & $\begin{array}{l}\text { Validase and alkaline protease F3 fractions } \\
\text { exerted remarkable DPPH and ABTS radical } \\
\text { scavenging abilities. Validase-F3 } \\
(500 \mu \mathrm{g} / \mathrm{g}) \text { inhibited lipid oxidation by } 19 \text { and } \\
15 \% \text { at days } 8 \text { and } 15 \text { of storage, respectively. }\end{array}$ & [122] \\
\hline Rice residue protein & $\begin{array}{l}\text { Alcalase, Flavourzyme, Protamex, } \\
\text { Pepsin, Trypsin, Papain }\end{array}$ & $\begin{array}{l}\text { RPNYTDA, TSQLLSDQ, TRTGDPFF, } \\
\text { NFHPQ }\end{array}$ & $<1 \mathrm{kDa}$, ultrafiltration, SEC, RP-FPLC & $\begin{array}{l}\text { RRPB3 fraction showed the strongest DPPH, } \\
\text { ABTS radical scavenging and FRAP-Fe }{ }^{3+} \text { reducing } \\
\text { activities. Synergistic activity was displayed by } \\
\text { RRPB3 I and III. }\end{array}$ & [123] \\
\hline Corn gluten meal & Neutrase & Hydrolysate & - & $\begin{array}{l}\text { Hydrolysate }\left(5 \mathrm{mg} \mathrm{mL}^{-1}\right) \text { inhibited lipid } \\
\text { oxidation in emulsion by reducing } \\
\text { hydroperoxides and TBARS formation. } \\
\text { F3 fraction from hydrolysate- } 5 \text { displayed higher }\end{array}$ & [124] \\
\hline Corn germ meal & Alcalase & MGGN, MNN, MEN & $<1 \mathrm{kDa}$, (ultra, gel filtration) & $\begin{array}{l}\text { DPPH, ABTS radical scavenging, and } \\
\text { ORAC activities. }\end{array}$ & [125] \\
\hline $\begin{array}{l}\text { Corn gluten meal and } \\
\text { distillers'- dried grains } \\
\text { with solubles (DDGS) }\end{array}$ & $\begin{array}{l}\text { Neutrase, } \\
\text { Alcalase }\end{array}$ & Hydrolysate & - & $\begin{array}{l}\text { Neutrase-hydrolyzed corn gluten meal }(2 \%) \\
\text { displayed the strongest oxidation prevention in } \\
\text { ground meat and significantly reduced TBARS in } \\
\text { pig feed. Alcalase-hydrolyzed DDGS retarded the } \\
\text { lipid oxidation by } 37.8 \% \text {. }\end{array}$ & [126] \\
\hline Corn protein isolate & $\begin{array}{l}\text { Microbial protease (Validase, } \\
\text { Alkaline, Neutral) }\end{array}$ & Hydrolysate & $<1-10 \mathrm{kDa}$, (ultrafiltration) & $\begin{array}{l}\text { Neutral protease fraction (NP-F3) demonstrated } \\
\text { the highest ORAC peroxyl radicals scavenging } \\
\text { activity. NP-F3 }(250 \text { and } 500 \mu \mathrm{g} / \mathrm{g}) \text { remarkably } \\
\text { inhibited lipid oxidation by } 52.9 \% \text { in ground beef. }\end{array}$ & [127] \\
\hline Corn gluten meal & Alcalase, Protamex & QQPQPW & $\begin{array}{c}<1 \mathrm{kDa} \text { (ultra, gel filtration and } \\
\text { RP-HPLC). }\end{array}$ & $\begin{array}{l}\text { Alcalase hydrolysate displayed the highest } \\
\text { antioxidant activity. Hexapeptide showed } \\
\text { remarkable DPPH, ABTS, and hydroxyl radical } \\
\text { scavenging activity, but weaker } \\
\mathrm{Fe}^{2+} \text {-chelating capacity. }\end{array}$ & [128] \\
\hline Corn gluten meal & $\begin{array}{c}\text { Alcalase, } \\
\text { Pepsin, pancreatin }\end{array}$ & YPQ, AYL & $<1 \mathrm{kDa}$ (ultra, gel filtration and RP-HPLC) & $\begin{array}{l}\text { Alcalase hydrolysates and GI-resistant peptides } \\
\text { exhibited higher DPPH, hydroxyl radical } \\
\text { scavenging and reduced power activity. }\end{array}$ & [129] \\
\hline Corn gluten meal & Papain, Ficin, Bromelain & Hydrolysate & $<1 \mathrm{kDa},>10 \mathrm{kDa}$ (ultra, gel filtration) & $\begin{array}{l}\text { Papain F4 fraction, ficin F1 fraction, and } \\
\text { bromelain F3 fraction showed the strongest DPPH } \\
\text { and ABTS radical scavenging and metal chelating } \\
\text { activity. Papain F4 fraction }(1000 \mathrm{mg} / \mathrm{kg} \text { ) reduced } \\
\text { lipid oxidation in ground meat by } 30.45 \% \text {. }\end{array}$ & [130] \\
\hline Corn gluten meal & $\begin{array}{c}\text { Alcalase, Flavourzyme, Alcalase + } \\
\text { Flavourzyme and Flavourzyme + } \\
\text { Alcalase }\end{array}$ & CSQAPLA, YPKLAPN, YPQLLPNE & $<1 \mathrm{kDa}$ (ultra, gel filtration and RP-HPLC & $\begin{array}{l}\text { Alcalase + Flavourzyme hydrolysate exhibited } \\
\text { better antioxidant activities. CSQAPLA displayed } \\
\text { the highest DPPH and superoxide anion radical } \\
\text { scavenging capacities, and good reducing } \\
\text { power activity. }\end{array}$ & [96] \\
\hline
\end{tabular}


Table 4. Cont.

\begin{tabular}{|c|c|c|c|c|c|}
\hline Protein Source & Enzyme & Peptide Sequence/Hydrolysate & Size & Assay Outcome & Reference \\
\hline Sorghum & Alcalase & VAITLTMK, VSKSVLVK & <1 kDa, (ultra, gel filtration, RP-UFLC) & $\begin{array}{l}\text { These peptides displayed the highest DPPH } \\
\text { radical scavenging activity. }\end{array}$ & [102] \\
\hline Sorghum & Alcalase & QQWQ, QWQQ & $<5-10 \mathrm{kDa}$, (ultra, gel filtration) & $\begin{array}{l}\text { Medium-sized hydrolysate fraction exhibited } \\
\text { stronger antioxidant activities based on DPPH, } \\
\text { ABTS, metal chelating, and reducing power assay. } \\
\text { The fraction also exerted remarkable lipid } \\
\text { oxidation inhibition, both in emulsion and in the } \\
\text { ground meat system. }\end{array}$ & [131] \\
\hline Finger millet & Trypsin, pepsin & $\begin{array}{l}\text { TSSSLNMAVRGGLTR, } \\
\text { STTVGLGISMRSASVR }\end{array}$ & $\begin{array}{c}<3 \mathrm{kDa} \text {, (ultra, gel filtration and } \\
\text { RP-UFLC) }\end{array}$ & $\begin{array}{l}\text { Trypsin fraction GFB exhibited the highest DPPH } \\
\text { and ABTS radical scavenging activity. In silico } \\
\text { interaction of serine and threonine residues with } \\
\text { free radicals potentially resulted in } \\
\text { antioxidant activity. }\end{array}$ & [101] \\
\hline Sorghum & Papain & $\begin{array}{l}\text { LRQQ, QLQGV, WQPN, GLQDL, } \\
\text { AMCGVV, YLRQ, TPCATS, } \\
\text { QGVAAA, AQVAQ, QQLQ }\end{array}$ & $1-3 \mathrm{kDa}$ (ultrafiltration and gel filtration) & $\begin{array}{l}\text { Kafirin hydrolysates }(1.0 \mathrm{mg} / \mathrm{g}) \text { inhibited TBARS } \\
\text { formation by } 32.1 \% \text { in meat samples. Fraction F3 } \\
\text { also exhibited the highest \% of DPPH radical } \\
\text { scavenging activity, metal chelating and } \\
\text { ORAC activity. }\end{array}$ & [132] \\
\hline Sorghum & $\begin{array}{l}\text { Alcalase, flavourzyme, neutrase, } \\
\text { everlase, protamex, papain, ficin, } \\
\text { bromelain, trypsin, Pepsin }\end{array}$ & Neutrase hydrolysate fractions & 3-10 kDa (ultra and gel filtration) & $\begin{array}{l}\text { Neutrase F2 hydrolysates fraction displayed } \\
\text { higher antioxidant activities (DPPH, ORAC, metal } \\
\text { chelating) and retarded lipid autoxidation and } \\
\text { peroxidation in the meat model. }\end{array}$ & [133] \\
\hline
\end{tabular}

ORAC: oxygen radical absorbance capacity; GI: gastrointestinal; TBARS: thiobarbituric acid reactive substances; N.R: not reported. 


\section{Production Strategies for Antioxidant Peptides}

Antioxidant peptides, like other functional peptides, are encrypted within the sequence of parent protein molecules and can be liberated through proteolytic enzyme hydrolysis, gastrointestinal digestion, or microbial fermentation. However, antioxidant peptides have been produced largely using enzymatic hydrolysis. In recent times, innovative and efficient food processing techniques, such as high hydrostatic pressure (HHP), microwave assistance (MA), ultrasonic assistance, pulsed electric field (PEF), and subcritical water have been employed in combination, or simultaneously, with conventional (classical) methods to improve yields and produce mono- or multifunctional peptides with lesser cost and time. These emerging technologies have been comprehensively discussed in recent reviews $[48,134]$. The production of antioxidant peptides from cereals and other plant sources is shown in Figure 3, and involves protein isolate pretreatment with novel food processing technologies (HHP, MA, PEF etc), followed by protease hydrolysis to obtain protein hydrolysate. Further purification steps using membrane separation, chromatographic methods, including ion-exchange chromatography (IEC), gel permeation chromatography (GPC), and reversed-phase high performance liquid chromatography (RP-HPLC), are performed to obtain antioxidant peptides, which are later identified by mass spectrometry (electrospray and tandem) and their activity is evaluated in vitro and in vivo tests $[66,135]$.

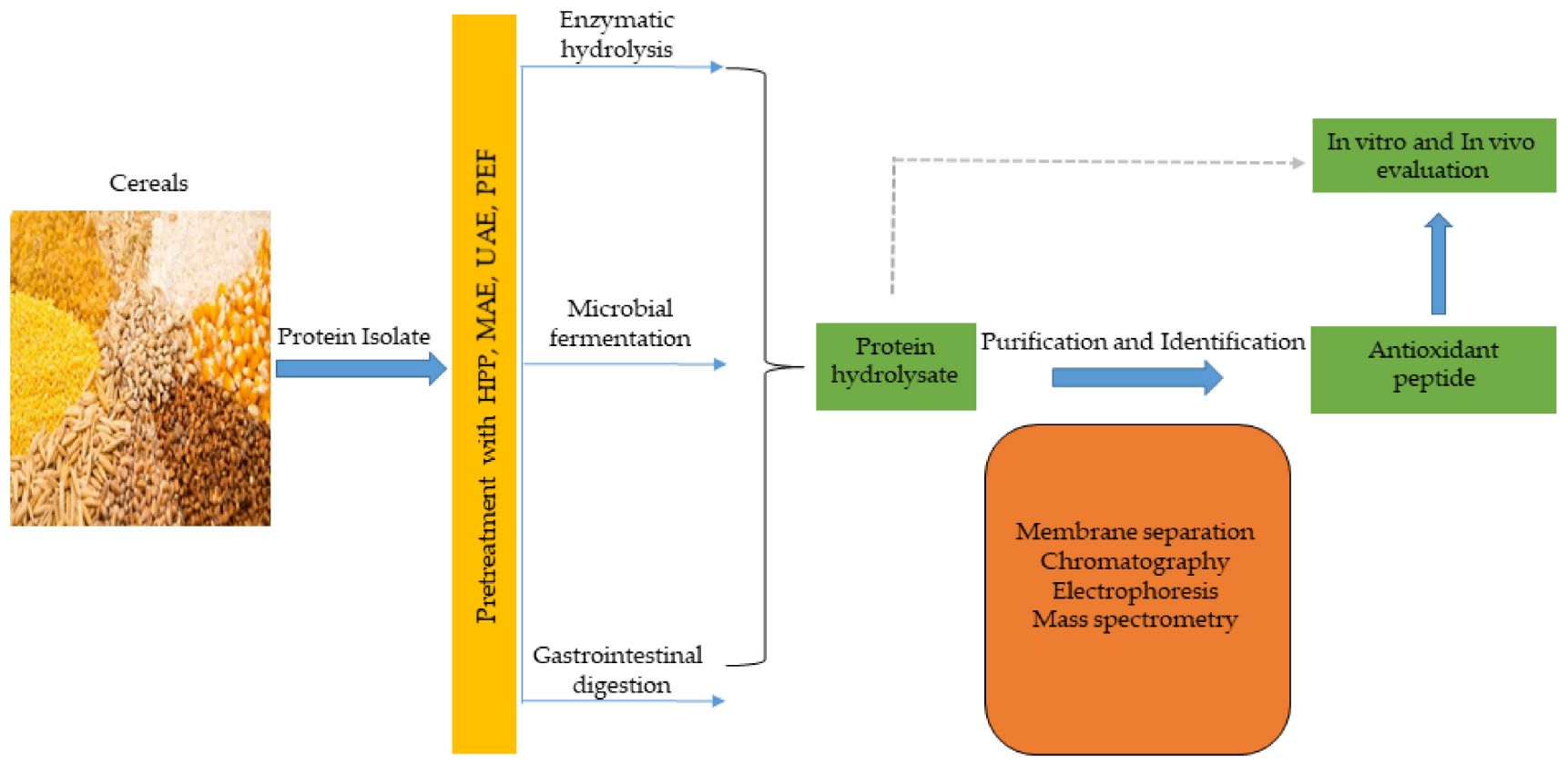

Figure 3. Cereal peptidic antioxidants production strategies.

\subsection{Conventional Approach}

\subsubsection{Enzymatic Hydrolysis}

Hydrolysis of food proteins to produce multi- or monofunctional peptides has been mainly conducted using enzymes. Bioactive peptides have gained much attention over the years and there has recently been particular interest in antioxidative peptides due to their potential multifunctional activities in the prevention and management of several diseases. Exogenous enzymes, specifically those from microbial sources (Alcalase, Flavourzyme and Protamex ${ }^{\mathrm{TM}}$ ), animal sources (pepsin and trypsin), and plant sources (e.g., papain), have extensively been used to produce antioxidative peptides [136]. Compared with the preparation methods of other peptides, the enzymatic hydrolysis method has the advantages of absence of organic solvents or toxic chemicals, easy reaction control, good repeatabil- 
ity, low cost, and low energy consumption. Therefore, it is the most widely preferred method for industrial production. However, decreasing hydrolysis time, the amount of enzyme, and improving the yield and bioactivity of peptides remain main challenges to be circumvented [137]. Consequently, innovative and emerging technologies, such as high hydrostatic pressure (HHP), microwave, and pulsed electric field, are being used to induce protein unfolding and activation of enzymes, thereby improving the efficiency of enzyme hydrolysis and generating peptide fractions with strong antioxidant activities [134]. The application of emerging technologies to produce high value BP will be discussed in detail later in this review.

The generation of protein hydrolysates and/or peptides with desirable functional properties is mainly affected by several factors, such as the types of enzyme and hydrolysis conditions (temperature, $\mathrm{pH}$, the ratio of enzyme to substrate, and time), among others. It is worth noting that different types of enzymes can specifically cleave different positions of the peptide. For example, pepsin digestion increases hydrophobicity by cleaving peptide bonds between hydrophobic amino acids (preferably aromatic amino acids, including Phe, Trp, and Tyr), resulting in an appropriate reaction of rice bran protein hydrolysates (RBPH) with DPPH free radicals. Nonetheless, a reduction in this ability was observed due to the action of trypsin, which further selectively cleaves basic amino acids [120]. Thus, the type of peptidase is crucial in determining the size, composition, and amino acid sequence of the peptides, and thus affects antioxidant activity [138]. Peptidase is mainly divided into animal, plant, and microbial proteases. In general, pepsin and trypsin are the most widely used animal proteases. Suetsuna and Chen [111] reported that the two peptides (Leu-GlnPro-Gly-Gln-Gly-Gln-Gln-Gly and Ala-Gln-Ile-Pro-Gln-Gln) obtained from wheat gluten protein by using pepsin have good antioxidant capacities. The digestion of food proteins by digestive enzymes, or enzymes produced by microbial flora residing in the gut, offers another opportunity to produce peptides with antioxidative activities directly or indirectly in the gut, or through cell signaling pathways or their ability to enter blood circulation by crossing epithelial cell membrane to target sites $[136,139]$. Therefore, the stability or resistance of food-derived antioxidative peptides to GI breakdown or modification is an essential factor to be considered to ensure they exert their beneficial health properties.

\subsubsection{Microbial Fermentation}

Microorganisms degrade food components through their complex enzyme systems. Bacteria belonging to the Lactobacillus genus are largely used for microbial fermentation to produce foods with improved nutritional properties and functional health benefits. Lactic acid bacteria (LAB) have a long history of use in fermented foods, and are generally regarded as safe (GRAS) [140,141]. An extracellular proteinase, a transport system specific for small peptides, and a multitude of intracellular specific, generic, endo-, and eso-peptidases constitute the proteolytic system of LAB [142]. Cereals are key components of daily diets in most parts of the world and, hence, their fermentation generates peptides with great biological importance. Antioxidant properties of cereals have been improved via the use of microbial bioprocessing and endogenous proteolytic enzymes to release antioxidant peptides and phenolic compounds from plant matrix. Antioxidant peptides have been produced and isolated from the sourdough fermentation of cereals [143]. Different strains have been reported to possess different proteolytic and peptidase activities on cereal proteins to release several peptides [141,143,144]. Galli et al. [143] revealed that different lactobacilli showed specific proteolytic and peptidase activity in wheat sourdough, which resulted in the production of low molecular weight peptides that exerted antioxidant and antiinflammatory activities on RAW 264.7 murine macrophage, murine $\mathrm{H}$-end endothelium cells, and human intestinal Caco-2 cells.

The effects of cooking on the anti-inflammatory and antioxidant properties of wheat sourdoughs and bread produced by three Lactobacilli strains (L. farciminis H3 and A11 and L. sanfranciscensis I4) were assessed by Luti et al. [145]. Peptides from dough and bread were found to suppress the NFkB pathway and, also, to reduce intracellular ROS 
levels. Biological activities were retained after cooking, despite differences in amino acid compositions and sequences between dough and bread peptides. Wheat germ fermented with Lactobacillus plantarum DY-1 exhibited a hydroxyl radical scavenging capacity of $72.8 \pm 2.9 \%$ and retarded thiobarbituric acid-reactive substances (TBARSs) formation in emulsified sausages stored at $4{ }^{\circ} \mathrm{C}$ for 7 days [146]. Niu et al. [147] found promising antioxidant activities from peptides (less than $1 \mathrm{kDa}$ ) obtained by fermentation of wheat germ with Bacillus Subtilis B1. They observed significant $\mathrm{EC}_{50}$ dose-dependent DPPH, hydroxyl and superoxide anion radical scavenging activities of $3.16 \mathrm{mg} / \mathrm{mL}, 6.04 \mathrm{mg} / \mathrm{mL}$ and $7.46 \mathrm{mg} / \mathrm{mL}$, respectively. Studies by Wang et al. [148] showed that co-fermentation of barley with Lactobacillus plantarum and Rhizopus oryzae increased amino acid nitrogen, $<10 \mathrm{kDa}$ peptide, and free phenolic contents, and thus improved DPPH, hydroxyl, $\mathrm{ABTS}^{+}$radical scavenging activity, and ferric reducing antioxidant power. Hydrolysates obtained during the fermentation of amaranth protein fractions with Lactobacillus helveticus and Lactobacillus plantarum possessed higher peroxyl and hydroxyl radical scavenging activities [149].

\subsection{Bioinformatics Approach}

Owing to the challenges involved in developing BP using classical approaches, which include time consumption, high cost, and uncertainties regarding the bioactivities of protein hydrolysates or fragment peptides which needs to be validated, bioinformatics could be a promising tool to discover bioactive peptides from different protein sources $[150,151]$. Bioinformatics, or in silico analysis, employs computational and statistical techniques to manage, curate, predict and interpret biological datasets [150]. Bioinformatics can minimize the number of experiments that must be performed to prepare BP by determining how their structure relates to their activity. Recently, researchers have employed the in silico approach to predict the production of BP from food proteins using bioinformatics and databases. This strategy, combined with classical approaches, can determine the optimum BP production parameters, such as the type of enzyme and target activity. In silico analysis has been used to predict peptides released by single and multiple enzyme digestion. Amino acid sequences and positions are key determinants of the bioactivities of peptides [152]. Several studies have attributed the bioactivies of peptides to the presence of some specific amino acids. For example, the amino acids cysteine $(\mathrm{C})$, histidine $(\mathrm{H})$, proline $(\mathrm{P})$, methionine $(\mathrm{M})$, and aromatic amino acids of food peptides have been reported to exert antioxidant activity [153]. Molecular docking approaches are used to predict and estimate the binding modes and affinities of small molecules within the binding sites of target receptors [154]. They have been used to screen for food-derived BP and illustrate their biological mechanisms. Protein structure selection and preparation, ligand preparation, docking, and analysis of results are the main steps involved in molecular docking [151]. In addition, bioinformatics approaches could be used to simulate and predict gastrointestinal stability, toxicity and allergenicity of peptides. Nonetheless, in vitro and in vivo validation of such a prediction needs to be carried out and ascertained. The bioavailability of antioxidant peptides is mainly affected by their transepithelial transport, and the human Caco-2 cell model is widely used for in vitro studies to investigate potential relevance in in vivo metabolism [135]. The in vivo challenges encountered by peptides as therapeutics has been comprehensively discussed by Yap and Gan [155]. Despite its wide use, increasing prediction accuracy of this computational tool can help overcome some theoretical and computational drawbacks.

Quantitative structure-activity relationship (QSAR) modeling reveals how the structural characteristics of compounds relates to their biochemical and functional properties. QSAR model development involves the following steps: (i) retrieving sequences of target peptides from a database or library; (ii) scalar description of amino acids constituents; (iii) QSAR model construction and activity prediction; and (iv) validation of synthesized peptides in vitro or in vivo. However, QSAR approaches are not without their limitations, as model development is difficult with lack of knowledge and the unavailability of protein sequences in protein libraries and online databases [156]. The reliability and predictability 
of a three-dimensional quantitative structure-activity relationship (3D-QSAR) model was developed using a combination of comparative molecular field analysis (CoMFA) and comparative similarity index analysis (CoMSIA), for a total of 198 antioxidant tripeptides retrieved from literature. Promising antioxidant activity was demonstrated from graphical contour maps of the model with significant contribution by electrostatic, steric, hydrophilic and hydrogen bond acceptor force fields. Consequently, ten novel tripeptides were designed with residue substitution, and their antioxidant activities were predicted by the model. Subsequently, the tripeptides were synthesized and validated by FRAP (ferric reducing antioxidant Potential) and ABTS (2,2'-azino-bis (3-ethlbenzthiazoline-6-sulfonic acid)) assays. Tripeptides WKW, GRC, ARW, LRW, LKW, and YKW showed higher ferric reducing capacity and ABTS radical scavenging capacity. Findings from this work showed a high correlation between experimental and predicted activity, and the developed model could provide insight regarding the structure and activity relationship of antioxidant peptides and be useful in their virtual screening and design [157]. Yan et al. [158] designed two novel tripeptides, GWY and QWY, using 3D-QSAR models, which demonstrated strong antioxidant activities of $3.32 \mathrm{mM}$ TE and $2.97 \mathrm{mM}$ TE, respectively; after synthesis and in vitro confirmatory evaluation using Trolox equivalent antioxidant capacity (TEAC) assay. These authors further investigated the potential molecular mechanism using molecular docking and molecular dynamics simulations. Their findings revealed that GWY and QWY could improve the body's antioxidant defense system by competitively binding to Keap1's active sites key residues Arg415, Arg483, Arg380 and Ser555, increasing the accumulation of Nrf2 and, hence, activating the Kelch-like ECH associated protein1 (Keap1)-nuclear factor erythroid 2-related factor 2 (Nrf2)-antioxidant response element (ARE) signaling pathway.

\subsection{Emerging Food Processing Technologies}

The potential application of innovative and emerging food processing techniques to improve food-derived protein digestibility, and produce BP of interest, is increasingly being explored (Table 5). HHP, a non-thermal and green technology which instantaneously and uniformly transmits isostatic pressure (100-1000 MPa) to enhance shelf life, improves the functional and bioactive properties of food products, and is an effective strategy to produce antioxidant peptides from various food sources. HHP treatment induces denaturation of native protein by disrupting hydrogen, as well as hydrophobic and ionic bonds, but not covalent and non-covalent bonds; hence, it modifies protein secondary structure but not the primary structure. Without the use of high temperatures, pressurization may improve the susceptibility of unfolded proteins access to enzyme hydrolysis $[159,160]$. Ultrasonication uses microbubble cavitation, and is considered an environmentally friendly food processing technique with higher yield, extraction rate, reproducibility, purity, minimal energy, water and solvent use. However, several factors, including ultrasound power, intensity, frequency, temperature, solvent, reactor design, as well as matrix parameters, are known to beneficially or negatively influence food components and metabolites [161]. Ultrasonication has been shown to increase protein extraction and sorghum digestibility. Sullivan et al. [162] found that ultrasonication at $40 \%$ amplitude for 10 min increased the solubility of sorghum kafirin protein from $6.5 \mu \mathrm{g} / \mathrm{mL}$ to $173.3 \mu \mathrm{g} / \mathrm{mL}$, as well as its digestibility as a result of its secondary structure modification. In addition, ultrasonication followed by in vitro pepsinpancreatin hydrolysis improved the antioxidant capacity of purified kafirin and sorghum gluten-like flour. Thus, ultrasonication could serve as a potential technique to improve the nutritional benefits and functionality of sorghum flour. Electron beam irradiation (EBI), an ionizing irradiation, is a safe, nonthermal, less expensive, and environmentally friendly technique used widely to modify food components and improve functional properties [163]. The functional and antioxidant properties of alcalase hydrolysates of wheat germ protein was remarkably improved after EBI treatment [164]. Li et al. [165] assessed the effect of EBI treatment on the structure and antioxidant activity of rice protein after alcalase hydrolysis. Even though EBI treatment induced amino acid oxidation as irradiation doses increased to $50 \mathrm{kGy}$, it caused changes in the secondary structure and hydrophobic regions 
in protein cores, leading to more fragmentations of hydrolysates and improvement in the antioxidant ability of rice protein. Irradiation at $50 \mathrm{kGy}$ increased the DPPH and ABTS radical scavenging activity to $96.8 \%$ and $92.0 \%$, respectively, compared to the $66.7 \%$ and $71.1 \%$ observed in non-irradiated rice protein hydrolysates.

Table 5. Cereal antioxidant peptides using different processing methods.

\begin{tabular}{|c|c|c|c|c|}
\hline Protein Source & Processing Method & $\begin{array}{c}\text { Peptide } \\
\text { Sequence/Size/Hydrolysate }\end{array}$ & Assay Outcome & Reference \\
\hline $\begin{array}{l}\text { Wheat germ protein } \\
\text { hydrolysates }\end{array}$ & Electron beam irradiation (EBI) & $<1 \mathrm{kDa}$ & $\begin{array}{l}\text { Irradiation at } 50 \mathrm{kGy} \text { increased } \\
\text { DPPH and } \mathrm{ABTS}^{+} \text {radical } \\
\text { scavenging activity by } 45.77 \% \text { and } \\
52.52 \% \text {, respectively. }\end{array}$ & [164] \\
\hline Wheat germ & $\begin{array}{l}\text { Fermentation with } \\
\text { Bacillus subtilis }\end{array}$ & N.R & $\begin{array}{l}\text { Peptide content increased in } \\
\text { fermented samples compared to } \\
\text { non-fermented samples and resulted } \\
\text { in an increase in DPPH radical } \\
\text { scavenging, } \mathrm{Fe}^{2+} \text { chelating and } \mathrm{Fe}^{3+} \\
\text { reducing power activities. }\end{array}$ & [166] \\
\hline KAMUT $^{\circledR}$ Wheat & $\begin{array}{l}\text { Combination of enzyme } \\
\text { hydrolysis (Alcalase, Neutrase, } \\
\text { Flavourzyme) and fermentation } \\
\text { with (Lactobacillus spp. strains) }\end{array}$ & VLPPQQQY & $\begin{array}{l}\text { Stronger superoxide anion, hydroxyl } \\
\text { radicals, organic nitro-radicals } \\
\text { (ABTS, DPPH) scavenging, and lipid } \\
\text { peroxidation inhibition } \\
\text { was observed. }\end{array}$ & [167] \\
\hline Wheat germ & Subcritical water extraction & GPFGPE, FGE, $<1 \mathrm{kDa}$ & $\begin{array}{l}\text { Peptide fraction } 4 \text { showed the } \\
\text { strongest DPPH radical scavenging } \\
\text { activity and could effectively cross } \\
\text { Caco-2 intestinal epithelium cells. } \\
\text { Ultrasonication increased DH, DPPH }\end{array}$ & [168] \\
\hline Sorghum & $\begin{array}{l}\text { Ultrasonication combined with } \\
\text { pepsin-pancreatin hydrolysis }\end{array}$ & $<1 \mathrm{kDa}$ & $\begin{array}{l}\text { scavenging activity and ORAC } \\
\text { values. However, there was no } \\
\text { improvement in NO } \\
\text { scavenging activity. }\end{array}$ & [162] \\
\hline Rice dregs & $\begin{array}{l}\text { Angling method using } \\
\text { metal-organic framework } \\
\text { combined with } \\
\text { alcalase hydrolysis. }\end{array}$ & GDMNP, LLLRW & $\begin{array}{l}\text { Strong DPPH, superoxide anion, } \\
\text { hydroxyl radical scavenging and } \\
\mathrm{Fe}^{2+} \text { chelating activity was exhibited } \\
\text { by peptides. }\end{array}$ & [169] \\
\hline Rice & $\begin{array}{l}\text { Alcalase-assisted electron beam } \\
\text { irradiation (EBI) }\end{array}$ & Hydrolysate & $\begin{array}{l}\text { EBI treatment at } 50 \mathrm{kGy} \text { improved } \\
\text { DPPH }(96.81 \%) \text { and ABTS }(92.04 \%) \\
\text { radical scavenging activity. }\end{array}$ & [165] \\
\hline Corn gluten meal & $\begin{array}{l}\text { Ultrasonication assisted } \\
\text { alcalase hydrolysis }\end{array}$ & $\begin{array}{l}\text { SGV, LPF, LLPH, LLPF, FLPF, } \\
\text { AHL, LGV (<1 kDa) }\end{array}$ & $\begin{array}{l}\text { Ultrasonic pretreatment ( } 5 \mathrm{~W} / \mathrm{L}, 2 \\
\left.\mathrm{~s} / 2 \mathrm{~s} \text { on } / \text { off, } 50{ }^{\circ} \mathrm{C} \text {, and } 25 \mathrm{~min}\right) \\
\text { significantly increased } \mathrm{DH}, \mathrm{DPPH} \\
\text { and hydroxyl radical scavenging } \\
\text { activity and enhanced formation of } \\
\text { small size peptides. }\end{array}$ & [170] \\
\hline
\end{tabular}

\section{Potential Mechanisms of Cereal Peptidic Antioxidants in MetS Prevention}

Recent increase in MetS worldwide and its negative impact on quality of life has led to the search for food ingredients or materials with strong oxidative stress prevention properties. Owing to this, cereal antioxidant peptides have gained great attention among researchers. The amino acid composition, sequence and molecular weight are key factors that contribute to the antioxidant activities of peptides [80]. Due to the proteolytic actions of GI enzymes (pepsin, trypsin and chymotrypsin), BP may retain or lose their specific activities at targets sites upon oral ingestion. As such, in vitro activities may not necessarily translate into in vivo efficacies [155]. Over the years, the potential antioxidant mechanisms of peptides have mainly been investigated using in vitro chemical assays, in vitro cellular assays, and in vivo animal studies. Although in vivo mechanisms are not fully understood, the activation of the endogenous antioxidant defense system have been reported in vivo [135]. Radical scavenging properties, chelation of metal ions, and inhibition of lipid peroxidation assays are the in vitro chemical evaluation methods used to assess antioxidant capacities of peptides and other compounds. The two main mechanisms by which free radicals are deactivated in vitro are the hydrogen atom transfer (HAT) and single electron transfer 
(SET) [171]. The SET mechanism methods frequently used are the DPPH radical scavenging ability and the Trolox equivalent antioxidant capacity (TEAC), while oxygen radical absorption capacity (ORAC), total free radical capture antioxidant parameters (TRAP), and carotene bleach analysis utilizes the HAT mechanism. Ferric reducing antioxidant power (FRAP) and thiobarbituric acid (TBARS) are the most commonly used methods for evaluating metal ion chelation and lipid peroxidation inhibition of antioxidants, respectively [135]. Cell-based antioxidant evaluation assays provide a direct reflection of the cytoprotective abilities exerted on oxidation-induced damaged cells, compared to in vitro chemical methods (Table 6). Different human and non-human cell lines are commonly used to assess the antioxidant properties of peptides. Wang et al. [172] evaluated the underlying antioxidative mechanism of ADWGGPLPH, a wheat germ-derived peptide on hyperglycemia-induced oxidative stress in vascular smooth muscle cells (VSMCs). ADWGGPLPH significantly prevented cell proliferation induced by high glucose, reduced intracellular ROS production, and suppressed NOX4 protein expression (a key enzyme related to ROS production in vascular cells) via the PKC //AMPK signaling pathway. Furthermore, ADWGGPLPH treatment at $4 \mathrm{mg} / \mathrm{kg}$, administered intraperitoneally, enhanced antioxidant abilities by reducing liver MDA levels and increasing SOD expression and attenuated inflammatory cytokine (plasma levels of TNF- $\alpha$ and IL-1 $\beta$ ) generation in STZ-induced C57BL/ 6 diabetic mice. Thus, ADWGGPLPH as a dietary antioxidant supplement could be used to complement antihyperglycemic drugs in the treatment of diabetic vascular complications.

Although numerous studies have demonstrated the direct antioxidant actions of peptides in vitro using chemical assays, there is still limited understanding of their indirect activation of antioxidant and detoxifying molecular pathways in vivo (Table 7). Presently, the Keap1-Nrf2 signaling pathway is considered one of the plausible antioxidant mechanisms of peptides in vivo. Nuclear factor erythroid 2-related factor 2 (Nrf2) regulates cellular responses against environmental stresses, and is bound to Kelch-like ECH associated protein 1 (Keap1) in the cytoplasm under basal conditions. However, during oxidative stress conditions, Nrf2 is released from Keap1 and translocated into the nucleus, where it binds to antioxidant response elements (AREs) and upregulates target genes [173,174]. The indirect antioxidative effects of peptides have been shown to be mediated through the Keap1-Nrf2 pathway. The activation of Nrf2 protects cells from oxidative damage via the upregulation of antioxidant and detoxifying enzymes, such as heme oxygenase-1 (HO-1), glutathione reductase (GR), and $\mathrm{NAD}(\mathrm{P}) \mathrm{H}$ quinone oxidoreductase1 (NQO1). Oryza Peptide-P60 (OP60), a commercial rice peptide, was reported to increase intracellular glutathione levels. Moritani et al. [175] evaluated the mechanisms underlying the antioxidant potential of this peptide in HepG2 cells and mice models. Their results revealed the cytoprotective effect of OP60 via the Nrf2 signaling pathway. OP60 pretreatment of HepG2 cells at $5 \mathrm{mg} / \mathrm{mL}$ reduced cytotoxicity caused by $\mathrm{H}_{2} \mathrm{O}_{2}$ or acetaminophen (APAP). The mRNA level of genes encoding heavy and light subunits of $\gamma$-glutamylcysteine synthetase ( $\gamma$-GCS) and other antioxidant enzymes were increased by OP60 treatment, as well as the promotion of Nrf2 nuclear translocation. OP60 treatment at $500 \mathrm{mg} / \mathrm{kg}$ in mice prevented oxidative stress-induced liver injury by increasing glutathione levels, heavy subunits of $\gamma$-GCS, and heme oxygenase- 1 expression in the liver. Thus, OP60 could be utilized as a functional food or ingredient for the prevention or management of MetS associated with oxidative stress. Findings from Sullivan et al. [176] revealed an association between the anti-inflammatory potential of sorghum kafirin in LPS-induced inflammation in THP-1 cells, and a reduction of intracellular ROS production. This association may be due to the possibility of kafirin's ability to directly bind to LPS and inhibit LPS binding to its receptor, TLR4, in kafirin-treated THP-1 cells, thus reducing ROS production induced by LPS. Moreover, reduced secretion of pro-inflammatory cytokines (IL-1 $\beta$, IL- 6 and TNF- $\alpha$ ) could be due to decreased nuclear translocation of p65 NF- $\mathrm{kB}$ subunits and c-JUN, as a result of limited phosphorylation of ERK $1 / 2$ and JNK caused by a reduction in intracellular ROS production. 
The inhibition of Toll-like receptor 4 (TLR4) pathways and the suppression of NF- $\mathrm{kB}$ activation is one of the potential mechanisms by which antioxidative peptides exert their protective functions. The antioxidant effect of rice-derived bran bioactive peptides (RBAP), KHNRGDEF, on $\mathrm{H}_{2} \mathrm{O}_{2}$-induced oxidative injury in human umbilical vein endothelial cells (HUVECs) was evaluated by Liang et al. [177]. RBAP protected HUVECs against $\mathrm{H}_{2} \mathrm{O}_{2}$-induced oxidant injury by binding to, and inhibiting, Toll-like receptor 4 (TLR4) pathways and suppressing NF- $\mathrm{KB}$ activation. Cruz-Chamorro et al. [178] reported on the reduction of Type 1 T helper (Th1) and Th17 pro-inflammatory cytokines production, suggesting an improvement in cellular anti-inflammatory microenvironment by increasing Th2/Th1 and Th2/Th17 balances in phytohaemagglutinin-P (PHA)-stimulated human peripheral blood mononuclear cells (PBMCs) using alcalase-generated wheat germ protein hydrolysates (WGPHs) treatment. WGPHs improved the total antioxidant capacity by directly scavenging free radicals, increasing the reduced form of glutathione (GSH) levels, and reducing nitric oxide (NO) overproduction. The antioxidative and anti-inflammatory effects of three peptides (MPH-A-I, IALLIPF, and PFLF) from foxtail millet, obtained by alcalase hydrolysis, was evaluated in $\mathrm{H}_{2} \mathrm{O}_{2}$-induced human keratinocyte HaCaT cells and RAW264.7 murine macrophages [179]. Peptides (IALLIPF and PFLF) from millet prolamins demonstrated promising antioxidant activity by effectively reducing ROS production in $\mathrm{H}_{2} \mathrm{O}_{2}$-induced $\mathrm{HaCaT}$ cells, inhibiting MDA production, and increasing GSH levels more than the peptide fraction of MPH-A-I. Furthermore, peptides suppressed the production of NO and pro-inflammatory cytokines (TNF- $\alpha$, IL-1 $\beta$ and IL-6) in (lipopolysaccharide) LPS-stimulated RAW264.7 cells. In addition, pretreatment with millet peptides was found to suppress the production of phosphorylated proteins (P-p38, P-Erk 1/2, and P-JNK) in the MAPK pathway. The potential antioxidant and anticancer activities of papain-hydrolyzed sorghum kafirin peptide antioxidants in human hepatocarcinoma (HepG2) cells have been demonstrated by $\mathrm{Xu}$ et al. [132]. They found that after $72 \mathrm{~h}$ treatment, antioxidant peptides (1-3 kDa) at 50 and $200 \mu \mathrm{g} / \mathrm{mL}$ significantly inhibited the growth of HepG2 cells, without any negative effect on cell viability. Findings from Wang et al. [180] showed intracellular ROS scavenging activities and the regulation of antioxidant defense and ROS metabolism relevant gene expressions in HepG2 cells by alcalase-derived corn gluten hydrolysate (CGH). Pretreatment of cells with CGH1 enhanced the expression of several genes (GPX3, GPX5, SOD3, CYGB, SEPP1, and MT3) initially suppressed in $\mathrm{H}_{2} \mathrm{O}_{2}$-induced HepG2 oxidative damaged cells. The suppression of EPHX2 expression by CGH1, which could be attributed to its antioxidant effect, was associated with arachidonic acid metabolism shown by an increase in cellular epoxyeicosatrienoic acid (EET) and EET-phospholipids formation. Miscalculation and misinterpretation of effective animal doses are two of the main problems encountered in interspecies comparisons and safe starting dose determination for initial clinical trials. Reagan-Shaw et al. [181] proposed the use of a body surface area (BSA) normalization method as an appropriate means for translating doses from animal studies to human equivalent doses (HEDs); instead of using a simple conversion based on body weight, which oftentimes results in misinterpretation and inappropriate comparisons between species due to invalid or inaccurate calculations. The authors suggested BSA as a suitable conversion factor for clinical trials, as it correlates well with several mammalian biological parameters, such as oxygen utilization, basal metabolism, caloric expenditure, blood volume, circulating plasma proteins, and renal function. However, for an average $60 \mathrm{~kg}$ person, an estimated dose of $3891.6 \mathrm{mg}, 2432.4 \mathrm{mg}$, and $972 \mathrm{mg}$ is required for corn germ albumin peptide fraction 4, OP60 rice commercial peptide, corn gluten meal peptides, and wheat bran peptides HEDs of $64.86,40.54,16.22 \mathrm{mg} / \mathrm{kg}$, respectively (Table 7). These concentrations are not reasonably obtainable compared to a dose of $19.2 \mathrm{mg}$ and $447.60 \mathrm{mg}$ for wheat bran peptides, ADWGGPLPH and LRP, with an HED of 0.32 and $7.46 \mathrm{mg} / \mathrm{kg}$, respectively. In addition, the size of the peptide, the mode of administration-whether oral, injection or perfusion - and the delivery system have a great impact on peptide stability, transport, and bioavailability. 
Table 6. Cellular antioxidant effects of cereal peptides and hydrolysates.

\begin{tabular}{|c|c|c|c|c|c|}
\hline Protein Source & Enzyme & $\begin{array}{c}\text { Peptide Se- } \\
\text { quence/Hydrolysate }\end{array}$ & Cellular Model & Cellular Outcome & Reference \\
\hline Wheat germ & Trypsin, Alcalase & AREGETVVPG & $\begin{array}{l}\text { Vascular smooth } \\
\text { muscle cells }\end{array}$ & $\begin{array}{l}\text { High glucose-induced cell } \\
\text { growth and generation of } \\
\text { intracellular ROS was } \\
\text { significantly decreased by AOP } \\
(5 \mu \mathrm{M}) \text {. Suppression of PKC } \zeta \text {, } \\
\text { AKT and Erk } 1 / 2 \\
\text { phosphorylation, and inhibition } \\
\text { of Nox } 4 \text { protein expression by } \\
\text { AOP }(5 \mu \mathrm{M}) \text {. }\end{array}$ & [182] \\
\hline Wheat germ & neutral protease & ADWGGPLPH & $\begin{array}{l}\text { Vascular smooth } \\
\text { muscle cells }\end{array}$ & $\begin{array}{l}\text { High glucose-induced cell } \\
\text { proliferation and intracellular } \\
\text { ROS generation was } \\
\text { significantly reduced by } \\
\text { peptide at } 10 \mu \mathrm{M} \text { and } 20 \mu \mathrm{M} \text {. } \\
\text { Stimulation of AMPK activity, } \\
\text { inhibition of PKC }, \text { AKT and } \\
\text { Erk1/2 phosphorylation, and } \\
\text { suppression of NOX4 } \\
\text { protein expression. }\end{array}$ & [172] \\
\hline Wheat gluten protein & Alcalase & Protein hydrolysate & $\begin{array}{c}\text { Human } \\
\text { peripheral blood } \\
\text { mononuclear cells }\end{array}$ & $\begin{array}{l}\text { Hydrolysate }(0.5 \mathrm{mg} / \mathrm{mL}) \\
\text { directly scavenged free radicals, } \\
\text { increased GSH levels, reduced } \\
\text { NO overproduction, and, thus, } \\
\text { enhanced cells' antioxidant } \\
\text { capacity. Also, cell proliferation, } \\
\text { Th1 and Th17 pro-inflammatory } \\
\text { cytokines IFN- } \gamma \text { and and IL-17 } \\
\text { were reduced. }\end{array}$ & [178] \\
\hline Foxtail millet & Alcalase & PFLF, IALLIPF & $\begin{array}{c}\text { Human keratinocyte } \\
\text { HaCaT cells }\end{array}$ & $\begin{array}{l}\text { ROS, MDA production was } \\
\text { effectively reduced and GSH } \\
\text { levels increased by MPP ( } 300 \\
\mu \mathrm{g} / \mathrm{mL}) \text { in } \mathrm{H}_{2} \mathrm{O}_{2} \text {-induced } \\
\mathrm{HaCaT} \text { cells. }\end{array}$ & [179] \\
\hline Sorghum & Pepsin-pancreatin & Kafirin hydrolysate & $\begin{array}{l}\text { THP-1 human } \\
\text { macrophages }\end{array}$ & $\begin{array}{l}\text { Kafirin }(100 \mu \mathrm{g} / \mathrm{mL}) \text { reduced } \\
\text { LPS-induced intracellular ROS } \\
\text { production, inflammatory } \\
\text { cytokines (IL-1 } \beta, \text { IL- } 6 \text { and } \\
\text { TNF- } \alpha \text { ) production, and nuclear } \\
\text { translocation of p65 and c-JUN. }\end{array}$ & [176] \\
\hline Rice bran & - & KHNRGDEF & $\begin{array}{l}\text { Human umbilical } \\
\text { vein endothelial cells } \\
\text { (HUVECs) }\end{array}$ & $\begin{array}{l}\mathrm{H}_{2} \mathrm{O}_{2} \text {-induced HUVECs } \\
\text { oxidant injury was protected by } \\
\text { rice bran peptide }(0.1 \mathrm{mM}) \\
\text { supplementation via TLR4 } \\
\text { binding, pathway inhibition, } \\
\text { and suppression of } \\
\text { NF- } \mathrm{KB} \text { activation. }\end{array}$ & [177] \\
\hline Rice & - & $\begin{array}{l}\text { OP60 commercial } \\
\text { peptide }\end{array}$ & HepG2 cells & $\begin{array}{l}\mathrm{H}_{2} \mathrm{O}_{2-} \text { or APAP-induced HepG2 } \\
\text { cytotoxicity was reduced by } 5 \\
\text { mg/mL OP60 pretreatment via } \\
\text { glutathione homeostasis } \\
\text { restoration and increased } \\
\text { mRNA expression of } \\
\text { antioxidant enzymes. }\end{array}$ & [175] \\
\hline Corn & Alcalase & $\begin{array}{c}\text { Zein hy- } \\
\text { drolysate/peptides }\end{array}$ & HepG2 cells & $\begin{array}{l}\text { Hydrolysate showed higher } \\
\text { ORAC activity than native } \\
\text { proteins. Peptides } \\
\text { (1155.56-1781.63 ng/mL IC } 50 \text { ) } \\
\text { induced apoptosis at } 24 \mathrm{hr} \text { by } \\
\text { increasing caspase } 3 \text { expression. }\end{array}$ & [183] \\
\hline Corn germ meal & Alcalase & MGGN, MNN, MEN & HepG2 cells & $\begin{array}{l}\text { Peptides }(0.2 \mathrm{mM}) \text { significantly } \\
\text { reduced ROS generation in } \\
\mathrm{H}_{2} \mathrm{O}_{2} \text {-induced HepG2 cells. } \\
\text { MNN showed the highest } \\
\text { cellular antioxidant activity. }\end{array}$ & [125] \\
\hline
\end{tabular}


Table 6. Cont.

\begin{tabular}{|c|c|c|c|c|c|}
\hline Protein Source & Enzyme & $\begin{array}{c}\text { Peptide Se- } \\
\text { quence/Hydrolysate }\end{array}$ & Cellular Model & Cellular Outcome & Reference \\
\hline Corn gluten meal & Alcalase & $\begin{array}{c}\text { corn gluten } \\
\text { hydrolysate }(\mathrm{CGH} 1) \\
<1 \mathrm{kDa}\end{array}$ & HepG2 cells & $\begin{array}{l}\text { CGH1-pretreated cells at } 2.5 \\
\text { mg/mL upregulated the genes } \\
\text { GPX3, GPX5, SOD3, CYGB, } \\
\text { SEPP1, and MT3 involved in } \\
\text { antioxidant defense. CGH1 } \\
\text { suppressed EPHX2 expression, } \\
\text { increased cellular EETs, } \\
\text { EET-phospholipids formation, } \\
\text { and, thus, protected against } \\
\mathrm{H}_{2} \mathrm{O}_{2} \text {-induced HepG2 } \\
\text { cell damage. }\end{array}$ & [180] \\
\hline Corn gluten meal & Alcalase & GLLLPH & HepG2 cells & $\begin{array}{l}\text { Corn peptide fractions (CPF) at } \\
2.50 \mathrm{mg} / \mathrm{mL} \text { exhibited high } \\
\text { cellular antioxidant activities } \\
\text { and increased the levels of } \\
\text { intracellular antioxidant } \\
\text { enzymes (SOD, CAT, GR and } \\
\text { GSH) in oxidized HepG2 cells. }\end{array}$ & [73] \\
\hline
\end{tabular}

ROS: reactive oxygen species; AOP: antioxidant peptide; NOX: NADPH oxidase; PKC $\zeta$ : phospho-protein kinase $\zeta$; AMPK: AMP-activated protein kinase; Erk: extracellular signal-related kinase; AKT: Th1: Type $1 \mathrm{~T}$ helper; Th17: Type $17 \mathrm{~T}$ helper; IFN- $\gamma$ : interferon- $\gamma$; IL17: interleukin 17; GSH: reduced glutathione; GR: glutathione reductase; SOD: superoxide dismutase; CAT: catalase; NO: nitric oxide; MDA: malondialdehyde; MPP: millet prolamins peptides; LPS: lipopolysaccharide; TLR4: Toll-like receptor 4; EET: epoxyeicosatrienoic acid.

Table 7. Antioxidant effects of cereal-derived peptides and hydrolysates in animal models.

\begin{tabular}{|c|c|c|c|c|c|}
\hline Protein Source & Peptide/Hydrolysate & Purpose of Study & In Vivo Outcome & $\begin{array}{c}\text { BSA-Based Human } \\
\text { Equivalent Dose }(\mathrm{mg} / \mathrm{kg})\end{array}$ & Reference \\
\hline Wheat bran & $\begin{array}{l}\text { NL, QL, FL, HAL, } \\
\text { AAVL, AKTVF, } \\
\text { and TPLTR }\end{array}$ & $\begin{array}{l}\text { Investigated the blood } \\
\text { pressure lowering effects of } \\
\text { wheat protein hydrolysates } \\
\text { and peptides in spontaneous } \\
\text { hypertensive rats (SHR). }\end{array}$ & $\begin{array}{l}\text { Oral administration of }<1 \mathrm{kDa} \\
\text { peptides at } 100 \mathrm{mg} / \mathrm{kg} \text { showed a } \\
\text { better reduction of systolic blood } \\
\text { pressure }(-35 \mathrm{mmHg}) \text { after } 6 \mathrm{~h} \\
\text { compared to hydrolysate } \\
(-20 \mathrm{mmHg}) .\end{array}$ & 16.22 & [108] \\
\hline Wheat bran & LRP, LQP & $\begin{array}{l}\text { Evaluated the effects of } \\
\text { peptides on oxidative stress } \\
\text { and the AMPK signaling } \\
\text { pathway in HFD-induced } \\
\text { NASH C57BL/ } 6 \text { mice. }\end{array}$ & $\begin{array}{l}\text { NASH mice treated with } 0.20 \% \text { LRP } \\
\text { showed a remarkable decrease in } \\
\text { serum d-ROM and a significant } \\
\text { increase in BAP levels. } \\
\text { Administration of } 0.20 \% \text { LQP } \\
\text { increased phospho-AMPK } \\
\text { expression and decreased } \\
\text { phospho-ACC expression, thus } \\
\text { alleviating the severity of NASH. }\end{array}$ & 7.46 & [184] \\
\hline Wheat bran & ADWGGPLPH & $\begin{array}{l}\text { Assessed the antioxidative } \\
\text { and antidiabetic vascular } \\
\text { dysfunction effects of } \\
\text { peptide in STZ-induced } \\
\text { C57BL/ } 6 \text { mice. }\end{array}$ & $\begin{array}{l}\text { Administered peptide at } 4 \mathrm{mg} / \mathrm{kg} \\
\text { enhanced SOD expression and total } \\
\text { antioxidant capacity, and also } \\
\text { attenuated hyperglycemia-induced } \\
\text { inflammatory factors, such as } \\
\text { TNF- } \alpha \text { and IL- } 1 \beta \text {. }\end{array}$ & 0.32 & [172] \\
\hline Rice & $\begin{array}{l}\text { OP60 commercial } \\
\text { peptide }\end{array}$ & $\begin{array}{l}\text { Evaluated the protective } \\
\text { effect of OP60 against } \\
\text { APAP-induced hepatic } \\
\text { injury in mice. }\end{array}$ & $\begin{array}{l}\text { GSH synthesis and antioxidant } \\
\text { enzymes were induced by OP } 60 \\
\text { ( } 500 \mathrm{mg} / \mathrm{kg} \text { ) via activation of the } \\
\text { Nrf2 pathway. }\end{array}$ & 40.54 & [175] \\
\hline $\begin{array}{l}\text { Corn Gluten meal } \\
\text { (CGM) }\end{array}$ & $\begin{array}{l}\text { CGM peptides } \\
\quad(<10 \mathrm{kDa})\end{array}$ & $\begin{array}{l}\text { Investigated the antioxidant } \\
\text { capacity of CGMP produced } \\
\text { by solid-state fermentation } \\
\text { with Bacillus subtilis } \\
\text { MTCC } 5480 \text { in aging rats } \\
\text { induced with D-galactose. }\end{array}$ & $\begin{array}{l}\text { Serum and liver antioxidant } \\
\text { enzymes (SOD, catalase, } \\
\text { glutathione peroxidase) and total } \\
\text { antioxidant capacity activities } \\
\text { increased, with a decrease in MDA } \\
\text { in D-galactose-induced aging rats } \\
\text { fed CGMP }(250 \mathrm{mg} / \mathrm{kg} \mathrm{bw}) \text {. }\end{array}$ & 40.54 & [185] \\
\hline Corn germ meal & $\begin{array}{l}\text { Albumin peptides } \\
\text { fractions (APF- } 4 \text { ) }\end{array}$ & $\begin{array}{l}\text { Examined the } \\
\text { hepatoprotective effects of } \\
\text { APF- } 4 \text { in alcohol-induced } \\
\text { liver injury in mice. }\end{array}$ & $\begin{array}{l}\text { APF- } 4(800 \mathrm{mg} / \mathrm{kg} \text { bw) } \\
\text { administration significantly } \\
\text { reduced activities and levels of } \\
\text { hepatic (AST), ALT and MDA, and } \\
\text { increased activities of SOD, CAT } \\
\text { and GSH. }\end{array}$ & 64.86 & [186] \\
\hline
\end{tabular}

HFD: high-fat diet; AMPK: AMP-activated protein kinase; NASH: non-alcoholic steatohepatitis; d-ROM: diacron reactive oxygen metabolite; BAP: biological antioxidant potential; ACC: acetyl-CoA carboxylase; STZ: streptozotocin; TNF- $\alpha$ : tumor necrosis factor $\alpha$; IL-1 $\beta$ : interleukin$1 \beta$; Nrf2: nuclear factor erythroid 2-related factor 2; acetaminophen: APAP; SOD: superoxide dismutase; CAT: catalase; GSH-Px: glutathione peroxidase; MDA: malondialdehyde, BSA: body surface area. Human equivalent dose (HED) based on BSA was calculated according to the formula suggested by Reagan-Shaw et al. [181]. 


\section{Conclusions}

Cereals are important staple foods which account for a huge proportion of the human diet. Recent human and animal studies have revealed compelling evidence of the association between oxidative stress and MetS. This review highlights recent technological advancements in the production of antioxidant peptides from cereals, although large scale applicability is still lacking and is required in the future. The simultaneous application of green technologies, such as high hydrostatic pressure, ultrasonication, and electron beam irradiation with enzymatic and fermentation methods, can help improve protein digestibility and produce mono- and multifunctional peptides from cereals and their byproducts. The potential of cereal protein hydrolysate and peptides to prevent oxidative stress in vitro, using chemical and cellular-based assays, has been well documented in existing literature. However, in vivo evaluations in animals are still few, and they are also lacking in human studies. As such, future studies are needed to elucidate the potential of peptide antioxidants and their intestinal absorption mechanisms under physiological conditions. In addition, future clinical studies to establish optimum safe and efficacious doses are needed. In summary, cereal peptidic antioxidants have great potential to be developed as health-promoting functional ingredients, foods, or dietary supplements for the prevention and management of MetS.

Author Contributions: F.K.O. conceptualized and provided ideas for Section 1, completed Sections 5 and 6, coordinated and organized the writing of the entire manuscript; D.-J.F.M. completed Sections 1-4; E.B.-M.D. provided ideas for the entire manuscript, completed Section 7, checked the language and format of the manuscript; D.-H.O. provided the framework and checked the final quality of the paper. All authors have read and agreed to the published version of the manuscript.

Funding: This work was supported and funded by the Cooperative Research Program for Agriculture Science and Technology 602 Development (Project No. PJ0145652021), Rural Development Administration, Korea.

Acknowledgments: In this section, you can acknowledge any support given which is not covered by the author contribution or funding sections. This may include administrative and technical support, or donations in kind (e.g., materials used for experiments).

Conflicts of Interest: The authors declare no conflict of interest.

\section{References}

1. Breitenbach, M.; Eckl, P. Introduction to Oxidative Stress in Biomedical and Biological Research. Biomolecules 2015, 5, 1169-1170. [CrossRef]

2. Sies, H. On the history of oxidative stress: Concept and some aspects of current development. Curr. Opin. Toxicol. 2018, 7, 122-126. [CrossRef]

3. Salim, S. Oxidative stress and the central nervous system. J. Pharmacol. Exp. Ther. 2017, 360, 201-205. [CrossRef] [PubMed]

4. Sies, H.; Berndt, C.; Jones, D.P. Oxidative stress. Annu. Rev. Biochem. 2017, 86, 715-748. [CrossRef] [PubMed]

5. Sies, H. Oxidative stress: Concept and some practical aspects. Antioxidants 2020, 9, 852. [CrossRef] [PubMed]

6. Sies, H.; Jones, D.P. Reactive oxygen species (ROS) as pleiotropic physiological signalling agents. Nat. Rev. Mol. Cell Biol. 2020, 21, 363-383. [CrossRef] [PubMed]

7. Mitra, A.K. Antioxidants: A Masterpiece of Mother Nature to Prevent Illness. J. Chem. Rev. 2020, 2, 243-256.

8. Rahal, A.; Kumar, A.; Singh, V.; Yadav, B.; Tiwari, R.; Chakraborty, S.; Dhama, K. Oxidative stress, prooxidants, and antioxidants: The interplay. Biomed. Res. Int. 2014, 2014, 761264. [CrossRef]

9. Ofosu, F.K.; Elahi, F.; Daliri, E.B.-M.; Tyagi, A.; Chen, X.Q.; Chelliah, R.; Kim, J.-H.; Han, S.-I.; Oh, D.-H. UHPLC-ESI-QTOFMS/MS characterization, antioxidant and antidiabetic properties of sorghum grains. Food Chem. 2021, 337, 127788. [CrossRef]

10. Lu, Q.-B. Reaction Cycles of Halogen Species in the Immune Defense: Implications for Human Health and Diseases and the Pathology and Treatment of COVID-19. Cells 2020, 9, 1461. [CrossRef]

11. Olson, K.R. Reactive oxygen species or reactive sulfur species: Why we should consider the latter. J. Exp. Biol. 2020, 223, jeb196352. [CrossRef]

12. Parvez, S.; Long, M.J.; Poganik, J.R.; Aye, Y. Redox signaling by reactive electrophiles and oxidants. Chem. Rev. 2018, 118, 8798-8888. [CrossRef]

13. Semchyshyn, H.M. Reactive carbonyl species in vivo: Generation and dual biological effects. Sci. World J. 2014, 2014, 417842. [CrossRef] [PubMed] 
14. Mano, J.I.; Biswas, M.; Sugimoto, K. Reactive carbonyl species: A missing link in ROS signaling. Plants 2019, 8, 391. [CrossRef] [PubMed]

15. Lee, B.H.; Lopez-Hilfiker, F.D.; Veres, P.R.; McDuffie, E.E.; Fibiger, D.L.; Sparks, T.L.; Ebben, C.J.; Green, J.R.; Schroder, J.C.; Campuzano-Jost, P. Flight deployment of a high-resolution time-of-flight chemical ionization mass spectrometer: Observations of reactive halogen and nitrogen oxide species. J. Geophys. Res. Atmos. 2018, 123, 7670-7686. [CrossRef]

16. Möller, M.N.; Rios, N.; Trujillo, M.; Radi, R.; Denicola, A.; Alvarez, B. Detection and quantification of nitric oxide-derived oxidants in biological systems. J. Biol. Chem. 2019, 294, 14776-14802. [CrossRef]

17. Nakamura, T.; Lipton, S.A. Nitric oxide-dependent protein post-translational modifications impair mitochondrial function and metabolism to contribute to neurodegenerative diseases. Antioxid. Redox Signal. 2020, 32, 817-833. [CrossRef] [PubMed]

18. Davies, M.J.; Hawkins, C.L. The role of myeloperoxidase in biomolecule modification, chronic inflammation, and disease. Antioxid. Redox Signal. 2020, 32, 957-981. [CrossRef]

19. Yang, X.; Li, Y.; Li, Y.; Ren, X.; Zhang, X.; Hu, D.; Gao, Y.; Xing, Y.; Shang, H. Oxidative stress-mediated atherosclerosis: Mechanisms and therapies. Front. Physiol. 2017, 8, 600. [CrossRef]

20. Lushchak, V.I. Free radicals, reactive oxygen species, oxidative stress and its classification. Chem. Biol. Interact. 2014, 224, 164-175. [CrossRef]

21. Hermes-Lima, M. Oxygen in biology and biochemistry: Role of free radicals. Funct. Metab. Regul. Adapt. 2004, 1, 319-366.

22. Lushchak, V.I. Environmentally induced oxidative stress in aquatic animals. Aquat. Toxicol. 2011, 101, 13-30. [CrossRef]

23. Lushchak, V.I. Adaptive response to oxidative stress: Bacteria, fungi, plants and animals. Comp. Biochem. Physiol. Part C Toxicol. Pharmacol. 2011, 153, 175-190. [CrossRef]

24. Sies, H. (Ed.) Oxidative stress: Introductory remarks. In Oxidative Stress, 1st ed.; Academic Press: London, UK, $1985 ;$ pp. 1-8.

25. Roede, J.R.; Stewart, B.J.; Petersen, D.R. Hepatotoxicity of Reactive Aldehydes. In Comprehensive Toxicology, 2nd ed.; McQueen, C.A., Ed.; Elsevier: Oxford, MA, USA, 2010; Volume 9, pp. 581-594.

26. El-Fawal, H.A.N. Neurotoxicology. In Encyclopedia of Environmental Health, 1st ed.; Nriagu, J.O., Ed.; Elsevier: Burlington, MA, USA, 2011; Volume 4, pp. 87-106.

27. Ofosu, F.K.; Mensah, D.J.F.; Daliri, E.B.M.; Lee, B.H.; Oh, D.H. Probiotics, diet, and gut microbiome modulation in metabolic syndromes prevention. In Advances in Probiotics Microorganisms in Food and Health; Dhanasekaran, D., Narayanan, S., Eds.; Elsievier Academic Press: Philadelphia, PA, USA, 2021; in press.

28. Shankar, K.; Mehendale, H. Encyclopedia of toxicology. Oxidative Stress 2014, 20, 735-737.

29. Grundy, S.M. Metabolic syndrome. In Diabetes Complications, Comorbidities and Related Disorders, 1st ed.; Bonora, E., DeFronzo, R.A., Eds.; Springer: Cham, Switzerland, 2018; pp. 71-107.

30. Shoushou, I.M.; Melebari, A.N.; Alalawi, H.A.; Alghaith, T.A.; Alaithan, M.S.; Albriman, M.H.A.; Hawsawi, H. Evaluation of Metabolic Syndrome in Primary Health Care. Int. J. Pharm. Res. Allied Sci. 2020, 9, 52-55.

31. Swarup, S.; Goyal, A.; Grigorova, Y.; Zeltser, R. Metabolic syndrome. In Statpearls; StatPearls Publishing: Treasure Island, FL, USA, 2020.

32. Di Daniele, N.; Petramala, L.; Di Renzo, L.; Sarlo, F.; Della Rocca, D.G.; Rizzo, M.; Fondacaro, V.; Iacopino, L.; Pepine, C.J.; De Lorenzo, A. Body composition changes and cardiometabolic benefits of a balanced Italian Mediterranean Diet in obese patients with metabolic syndrome. Acta Diabetol. 2013, 50, 409-416. [CrossRef]

33. Aguilar, M.; Bhuket, T.; Torres, S.; Liu, B.; Wong, R.J. Prevalence of the metabolic syndrome in the United States, 2003-2012. JAMA 2015, 313, 1973-1974. [CrossRef]

34. Sigit, F.S.; Tahapary, D.L.; Trompet, S.; Sartono, E.; Van Dijk, K.W.; Rosendaal, F.R.; De Mutsert, R. The prevalence of metabolic syndrome and its association with body fat distribution in middle-aged individuals from Indonesia and the Netherlands: A cross-sectional analysis of two population-based studies. Diabetol. Metab. Syndr. 2020, 12, 1-11. [CrossRef]

35. Marcos-Delgado, A.; Hernández-Segura, N.; Fernández-Villa, T.; Molina, A.J.; Martín, V. The Effect of Lifestyle Intervention on Health-Related Quality of Life in Adults with Metabolic Syndrome: A Meta-Analysis. Int. J. Environ. Res. Public Health 2021, 18, 887. [CrossRef] [PubMed]

36. Shin, D.; Kongpakpaisarn, K.; Bohra, C. Trends in the prevalence of metabolic syndrome and its components in the United States 2007-2014. Int. J. Cardiol. 2018, 259, 216-219. [CrossRef]

37. Lesser, I.A.; Gasevic, D.; Lear, S.A. The effect of body fat distribution on ethnic differences in cardiometabolic risk factors of Chinese and Europeans. Appl. Physiol. Nutr. Metab. 2013, 38, 701-706. [CrossRef]

38. Furukawa, S.; Fujita, T.; Shimabukuro, M.; Iwaki, M.; Yamada, Y.; Nakajima, Y.; Nakayama, O.; Makishima, M.; Matsuda, M.; Shimomura, I. Increased oxidative stress in obesity and its impact on metabolic syndrome. J. Clin. Investig. 2017, 114, $1752-1761$. [CrossRef]

39. Bonomini, F.; Rodella, L.F.; Rezzani, R. Metabolic syndrome, aging and involvement of oxidative stress. Aging Dis. 2015, 6, 109. [CrossRef] [PubMed]

40. Li, L.; Yang, X. The essential element manganese, oxidative stress, and metabolic diseases: Links and interactions. Oxid. Med. Cell. Longev. 2018, 2018, 7580707. [CrossRef] [PubMed]

41. Monserrat-Mesquida, M.; Quetglas-Llabrés, M.; Capó, X.; Bouzas, C.; Mateos, D.; Pons, A.; Tur, J.A.; Sureda, A. Metabolic syndrome is associated with oxidative stress and proinflammatory state. Antioxidants 2020, 9, 236. [CrossRef] 
42. Spahis, S.; Borys, J.-M.; Levy, E. Metabolic syndrome as a multifaceted risk factor for oxidative stress. Antioxid. Redox Signal. 2017, 26, 445-461. [CrossRef] [PubMed]

43. Manna, P.; Jain, S.K. Obesity, oxidative stress, adipose tissue dysfunction, and the associated health risks: Causes and therapeutic strategies. Metab. Syndr. Relat. Disord. 2015, 13, 423-444. [CrossRef]

44. Lemes, A.C.; Sala, L.; Ores, J.D.C.; Braga, A.R.C.; Egea, M.B.; Fernandes, K.F. A review of the latest advances in encrypted bioactive peptides from protein-rich waste. Int. J. Mol. Sci. 2016, 17, 950. [CrossRef]

45. Sánchez, A.; Vázquez, A. Bioactive peptides: A review. Food Qual. Saf. 2017, 1, 29-46. [CrossRef]

46. Mora, L.; Gallego, M.; Aristoy, M.-C.; Reig, M.; Toldrá, F. Bioactive peptides. In Innovative Thermal and Non-Thermal Processing, Bioaccessibility and Bioavailability of Nutrients and Bioactive Compounds; Barba, F.J., Saraiva, J.M.A., Cravotto, G., Lorenzo, J.M., Eds.; Elsevier: Duxford, UK, 2019; pp. 333-345.

47. Amigo, L.; Hernández-Ledesma, B. Current evidence on the bioavailability of food bioactive peptides. Molecules 2020, $25,4479$. [CrossRef]

48. Tadesse, S.A.; Emire, S.A. Production and processing of antioxidant bioactive peptides: A driving force for the functional food market. Heliyon 2020, 6, e04765. [CrossRef]

49. Esfandi, R.; Walters, M.E.; Tsopmo, A. Antioxidant properties and potential mechanisms of hydrolyzed proteins and peptides from cereals. Heliyon 2019, 5, e01538. [CrossRef]

50. Micewicz, E.D.; Bahattab, O.S.; Willars, G.B.; Waring, A.J.; Navab, M.; Whitelegge, J.P.; McBride, W.H.; Ruchala, P. Small lipidated anti-obesity compounds derived from neuromedin U. Eur. J. Med. Chem. 2015, 101, 616-626. [CrossRef] [PubMed]

51. Hajfathalian, M.; Ghelichi, S.; García-Moreno, P.J.; Moltke Sørensen, A.-D.; Jacobsen, C. Peptides: Production, bioactivity, functionality, and applications. Crit. Rev. Food Sci. Nutr. 2018, 58, 3097-3129. [CrossRef]

52. Kumar, P.; Kizhakkedathu, J.N.; Straus, S.K. Antimicrobial peptides: Diversity, mechanism of action and strategies to improve the activity and biocompatibility in vivo. Biomolecules 2018, 8, 4. [CrossRef] [PubMed]

53. Xu, S.; Fan, F.; Liu, H.; Cheng, S.; Tu, M.; Du, M. Novel anticoagulant peptide from lactoferrin binding thrombin at the active site and exosite-I. J. Agric. Food Chem. 2020, 68, 3132-3139. [CrossRef] [PubMed]

54. Guha, S.; Majumder, K. Structural-features of food-derived bioactive peptides with anti-inflammatory activity: A brief review. J. Food Biochem. 2019, 43, e12531. [CrossRef] [PubMed]

55. Liu, Y.-F.; Oey, I.; Bremer, P.; Carne, A.; Silcock, P. Bioactive peptides derived from egg proteins: A review. Crit. Rev. Food Sci. Nutr. 2018, 58, 2508-2530. [CrossRef]

56. Lee, Y.-M.; Han, S.-I.; Song, B.C.; Yeum, K.-J. Bioactives in commonly consumed cereal grains: Implications for oxidative stress and inflammation. J. Med. Food 2015, 18, 1179-1186. [CrossRef]

57. Luo, J.; Zhou, Z.; Yao, X.; Fu, Y. Mineral-chelating peptides derived from fish collagen: Preparation, bioactivity and bioavailability. LWT 2020, 134, 110209. [CrossRef]

58. Amado, I.R.; González, M.P.; Murado, M.A.; Vázquez, J.A. Shrimp wastewater as a source of astaxanthin and bioactive peptides. J. Chem. Technol. Biotechnol. 2016, 91, 793-805. [CrossRef]

59. Chen, Y.; Chen, J.; Chen, J.; Yu, H.; Zheng, Y.; Zhao, J.; Zhu, J. Recent advances in seafood bioactive peptides and their potential for managing osteoporosis. Crit. Rev. Food Sci. Nutr. 2020, 23, 1-17. [CrossRef]

60. Gong, H.; Gao, J.; Wang, Y.; Luo, Q.; Guo, K.; Ren, F.; Mao, X. Identification of novel peptides from goat milk casein that ameliorate high-glucose-induced insulin resistance in HepG2 cells. J. Dairy Sci. 2020, 103, 4907-4918. [CrossRef] [PubMed]

61. Padghan, P.; Mann, B.; Hati, S. Purification and characterization of antioxidative peptides derived from fermented milk (lassi) by lactic cultures. Int. J. Pept. Res. Ther. 2018, 24, 235-249. [CrossRef]

62. Uraipong, C.; Zhao, J. Identification and functional characterisation of bioactive peptides in rice bran albumin hydrolysates. Int. J. Food Sci. Technol. 2016, 51, 2201-2208. [CrossRef]

63. Chatterjee, C.; Gleddie, S.; Xiao, C.-W. Soybean bioactive peptides and their functional properties. Nutrients $2018,10,1211$. [CrossRef] [PubMed]

64. Montone, C.M.; Capriotti, A.L.; Cavaliere, C.; La Barbera, G.; Piovesana, S.; Chiozzi, R.Z.; Laganà, A. Characterization of antioxidant and angiotensin-converting enzyme inhibitory peptides derived from cauliflower by-products by multidimensional liquid chromatography and bioinformatics. J. Funct. Foods 2018, 44, 40-47. [CrossRef]

65. Sila, A.; Bougatef, A. Antioxidant peptides from marine by-products: Isolation, identification and application in food systems. A review. J. Funct. Foods 2016, 21, 10-26. [CrossRef]

66. Wong, F.-C.; Xiao, J.; Wang, S.; Ee, K.-Y.; Chai, T.-T. Advances on the antioxidant peptides from edible plant sources. Trends Food Sci. Technol. 2020, 99, 44-57. [CrossRef]

67. Aluko, R. Amino acids, peptides, and proteins as antioxidants for food preservation. In Handbook of Antioxidants for Food Preservation, 1st ed.; Shahidi, F., Ed.; Woodhead Publishing: Cambridge, UK, 2015; pp. 105-140.

68. Power, O.; Jakeman, P.; FitzGerald, R. Antioxidative peptides: Enzymatic production, in vitro and in vivo antioxidant activity and potential applications of milk-derived antioxidative peptides. Amino Acids 2013, 44, 797-820. [CrossRef]

69. Selamassakul, O.; Laohakunjit, N.; Kerdchoechuen, O.; Yang, L.; Maier, C.S. Bioactive peptides from brown rice protein hydrolyzed by bromelain: Relationship between biofunctional activities and flavor characteristics. J. Food Sci. 2020, 85, 707-717. [CrossRef] [PubMed] 
70. Han, B.K.; Park, Y.; Choi, H.S.; Suh, H.J. Hepatoprotective effects of soluble rice protein in primary hepatocytes and in mice. J. Sci. Food Agric. 2016, 96, 685-694. [CrossRef] [PubMed]

71. Ren, D.; Zhao, F.; Liu, C.; Wang, J.; Guo, Y.; Liu, J.; Min, W. Antioxidant hydrolyzed peptides from Manchurian walnut (Juglans mandshurica Maxim.) attenuate scopolamine-induced memory impairment in mice. J. Sci. Food Agric. 2018, 98, 5142-5152. [CrossRef]

72. Wang, L.; Ding, L.; Wang, Y.; Zhang, Y.; Liu, J. Isolation and characterisation of in vitro and cellular free radical scavenging peptides from corn peptide fractions. Molecules 2015, 20, 3221-3237. [CrossRef]

73. Wang, L.; Ding, L.; Yu, Z.; Zhang, T.; Ma, S.; Liu, J. Intracellular ROS scavenging and antioxidant enzyme regulating capacities of corn gluten meal-derived antioxidant peptides in HepG2 cells. Food Res. Int. 2016, 90, 33-41. [CrossRef]

74. Sun, C.; Tang, X.; Ren, Y.; Wang, E.; Shi, L.; Wu, X.; Wu, H. Novel antioxidant peptides purified from mulberry (Morus Atropurpurea Roxb.) leaf protein hydrolysates with hemolysis inhibition ability and cellular antioxidant activity. J. Agric. Food Chem. 2019, 67, 7650-7659. [CrossRef]

75. Chalé, F.G.H.; Ruiz, J.C.R.; Fernández, J.J.A.; Ancona, D.A.B.; Campos, M.R.S. ACE inhibitory, hypotensive and antioxidant peptide fractions from Mucuna pruriens proteins. Process Biochem. 2014, 49, 1691-1698. [CrossRef]

76. Indiano-Romacho, P.; Fernández-Tomé, S.; Amigo, L.; Hernández-Ledesma, B. Multifunctionality of lunasin and peptides released during its simulated gastrointestinal digestion. Food Res. Int. 2019, 125, 108513. [CrossRef] [PubMed]

77. Adebayo, J.O.; Adewole, K.E.; Krettli, A.U. Cysteine-stabilised peptide extract of Morinda lucida (Benth) leaf exhibits antimalarial activity and augments antioxidant defense system in P. berghei-infected mice. J. Ethnopharmacol. 2017, 207, 118-128. [CrossRef] [PubMed]

78. Adewole, K.E.; Adebayo, J.O. Antioxidant defense system induced by cysteine-stabilized peptide fraction of aqueous extract of Morinda lucida leaf in selected tissues of Plasmodium berghei-infected mice. J. Integr. Med. 2017, 15, 388-397. [CrossRef]

79. Malaguti, M.; Dinelli, G.; Leoncini, E.; Bregola, V.; Bosi, S.; Cicero, A.F.; Hrelia, S. Bioactive peptides in cereals and legumes: Agronomical, biochemical and clinical aspects. Int. J. Mol. Sci. 2014, 15, 21120-21135. [CrossRef] [PubMed]

80. Nwachukwu, I.D.; Aluko, R.E. Structural and functional properties of food protein-derived antioxidant peptides. J. Food Biochem. 2019, 43, e12761. [CrossRef]

81. Edelstein, S. Food Science: An Ecological Approach, 1st ed.; Jones \& Bartlett Publishers: Burlington, MA, USA, $2014 ;$ pp. 1-495.

82. Ortiz-Martinez, M.; Winkler, R.; García-Lara, S. Preventive and therapeutic potential of peptides from cereals against cancer. J. Proteom. 2014, 111, 165-183. [CrossRef]

83. Díaz-Gómez, J.L.; Castorena-Torres, F.; Preciado-Ortiz, R.E.; García-Lara, S. Anti-cancer activity of maize bioactive peptides. Front. Chem. 2017, 5, 44. [CrossRef] [PubMed]

84. Thielecke, F.; Lecerf, J.-M.; Nugent, A.P. Processing in the food chain: Do cereals have to be processed to add value to the human diet? Nutr. Res. Rev. 2020, 28, 1-15. [CrossRef] [PubMed]

85. Walsh, J.; Haddock, J.; Blumberg, J.B.; McKay, D.L.; Wei, X.; Dolnikowski, G.; Chen, C.-Y.O. Identification of methylated metabolites of oat avenanthramides in human plasma using UHPLC QToF-MS. Int. J. Food Sci. Nutr. 2018, 69, 377-383. [CrossRef]

86. Green, P.H.; Lebwohl, B.; Greywoode, R. Celiac disease. J. Allergy Clin. Immunol. 2015, 135, 1099-1106. [CrossRef]

87. Syage, J.A.; Kelly, C.P.; Dickason, M.A.; Ramirez, A.C.; Leon, F.; Dominguez, R.; Sealey-Voyksner, J.A. Determination of gluten consumption in celiac disease patients on a gluten-free diet. Am. J. Clin. Nutr. 2018, 107, 201-207. [CrossRef]

88. Cian, R.E.; Vioque, J.; Drago, S.R. Structure-mechanism relationship of antioxidant and ACE I inhibitory peptides from wheat gluten hydrolysate fractionated by pH. Food Res. Int. 2015, 69, 216-223. [CrossRef]

89. Ngamsuk, S.; Hsu, J.-L.; Huang, T.-C.; Suwannaporn, P. Ultrasonication of milky stage rice milk with bioactive peptides from rice bran: Its bioactivities and absorption. Food Bioprocess Technol. 2020, 13, 462-474. [CrossRef]

90. Bamdad, F.; Wu, J.; Chen, L. Effects of enzymatic hydrolysis on molecular structure and antioxidant activity of barley hordein. J. Cereal Sci. 2011, 54, 20-28. [CrossRef]

91. Giriwono, P.E.; Hashimoto, T.; Ohsaki, Y.; Shirakawa, H.; Hokazono, H.; Komai, M. Extract of fermented barley attenuates chronic alcohol induced liver damage by increasing antioxidative activities. Food Res. Int. 2010, 43, 118-124. [CrossRef]

92. Tok, K.; Moulahoum, H.; Kocadag Kocazorbaz, E.; Zihnioglu, F. Bioactive peptides with multiple activities extracted from Barley (Hordeum vulgare L.) grain protein hydrolysates: Biochemical analysis and computational identification. J. Food Process. Preserv. 2021, 45, e15024. [CrossRef]

93. Leung, R.; Venus, C.; Zeng, T.; Tsopmo, A. Structure-function relationships of hydroxyl radical scavenging and chromium-VI reducing cysteine-tripeptides derived from rye secalin. Food Chem. 2018, 254, 165-169. [CrossRef]

94. Coda, R.; Rizzello, C.G.; Pinto, D.; Gobbetti, M. Selected lactic acid bacteria synthesize antioxidant peptides during sourdough fermentation of cereal flours. Appl. Environ. Microbiol. 2012, 78, 1087-1096. [CrossRef]

95. Tang, N.; Zhuang, H. Evaluation of antioxidant activities of zein protein fractions. J. Food Sci. 2014, 79, C2174-C2184. [CrossRef] [PubMed]

96. Jin, D.-X.; Liu, X.-L.; Zheng, X.-Q.; Wang, X.-J.; He, J.-F. Preparation of antioxidative corn protein hydrolysates, purification and evaluation of three novel corn antioxidant peptides. Food Chem. 2016, 204, 427-436. [CrossRef]

97. Majid, A.; Priyadarshini CG, P. Millet derived bioactive peptides: A review on their functional properties and health benefits. Crit. Rev. Food Sci. Nutr. 2020, 60, 3342-3351. [CrossRef] 
98. Bandyopadhyay, T.; Muthamilarasan, M.; Prasad, M. Millets for next generation climate-smart agriculture. Front. Plant Sci. 2017, 8, 1266. [CrossRef]

99. Anitha, S.; Govindaraj, M.; Kane-Potaka, J. Balanced amino acid and higher micronutrients in millets complements legumes for improved human dietary nutrition. Cereal Chem. 2020, 97, 74-84. [CrossRef]

100. Hu, S.; Yuan, J.; Gao, J.; Wu, Y.; Meng, X.; Tong, P.; Chen, H. Antioxidant and Anti-Inflammatory Potential of Peptides Derived from In Vitro Gastrointestinal Digestion of Germinated and Heat-Treated Foxtail Millet (Setaria italica) Proteins. J. Agric. Food Chem. 2020, 68, 9415-9426. [CrossRef] [PubMed]

101. Agrawal, H.; Joshi, R.; Gupta, M. Purification, identification and characterization of two novel antioxidant peptides from finger millet (Eleusine coracana) protein hydrolysate. Food Res. Int. 2019, 120, 697-707. [CrossRef] [PubMed]

102. Agrawal, H.; Joshi, R.; Gupta, M. Isolation and characterisation of enzymatic hydrolysed peptides with antioxidant activities from green tender sorghum. LWT Food Sci. Technol. 2017, 84, 608-616. [CrossRef]

103. de Morais Cardoso, L.; Pinheiro, S.S.; Martino, H.S.D.; Pinheiro-Sant'Ana, H.M. Sorghum (Sorghum bicolor L.): Nutrients, bioactive compounds, and potential impact on human health. Crit. Rev. Food Sci. Nutr. 2017, 57, 372-390. [CrossRef] [PubMed]

104. Mohajeri, M.H.; Eckert, G.P.; Pauly, J.R.; Butt, C.M. Pharmacology: The Pharmacodynamics of Nutrients and Nutrient Interactions in Biological Functions. Biomed Res. Int. 2015, 2015, 974572. [CrossRef]

105. Stefoska-Needham, A.; Beck, E.J.; Johnson, S.K.; Tapsell, L.C. Sorghum: An underutilized cereal whole grain with the potential to assist in the prevention of chronic disease. Food Rev. Int. 2015, 31, 401-437. [CrossRef]

106. Massoud, M.I.; Abd El-Razek, A.M. Suitability of Sorghum bicolor L. stalks and grains for bioproduction of ethanol. Ann. Agric. Sci. 2011, 56, 83-87. [CrossRef]

107. Moraes, É.A.; Natal, D.I.G.; Queiroz, V.A.V.; Schaffert, R.E.; Cecon, P.R.; de Paula, S.O.; dos Anjos Benjamim, L.; Ribeiro, S.M.R.; Martino, H.S.D. Sorghum genotype may reduce low-grade inflammatory response and oxidative stress and maintains jejunum morphology of rats fed a hyperlipidic diet. Food Res. Int. 2012, 49, 553-559. [CrossRef]

108. Zou, Z.; Wang, M.; Wang, Z.; Aluko, R.E.; He, R. Antihypertensive and antioxidant activities of enzymatic wheat bran protein hydrolysates. J. Food Biochem. 2020, 44, e13090. [CrossRef]

109. Zhao, Y.; Zhao, Q.; Lu, Q. Purification, structural analysis, and stability of antioxidant peptides from purple wheat bran. BMC Chem. 2020, 14, 1-12. [CrossRef]

110. Karami, Z.; Peighambardoust, S.H.; Hesari, J.; Akbari-Adergani, B.; Andreu, D. Identification and synthesis of multifunctional peptides from wheat germ hydrolysate fractions obtained by proteinase K digestion. J. Food Biochem. 2019, 43, e12800. [CrossRef] [PubMed]

111. Suetsuna, K.; Chen, J.-R. Isolation and characterization of peptides with antioxidant activity derived from wheat gluten. Food Sci. Technol. Res. 2002, 8, 227-230. [CrossRef]

112. Karami, Z.; Peighambardoust, S.H.; Hesari, J.; Akbari-Adergani, B.; Andreu, D. Antioxidant, anticancer and ACE-inhibitory activities of bioactive peptides from wheat germ protein hydrolysates. Food Biosci. 2019, 32, 100450. [CrossRef]

113. Elmalimadi, M.B.; Stefanović, A.B.; Šekuljica, N.Ž.; Žuža, M.G.; Luković, N.D.; Jovanović, J.R.; Knežević-Jugović, Z.D. The synergistic effect of heat treatment on alcalase-assisted hydrolysis of wheat gluten proteins: Functional and antioxidant properties. J. Food Process. Preserv. 2017, 41, e13207. [CrossRef]

114. Zaky, A.A.; Chen, Z.; Liu, Y.; Li, S.; Jia, Y. Preparation and assessment of bioactive extracts having antioxidant activity from rice bran protein hydrolysates. J. Food Meas. Charact. 2019, 13, 2542-2548. [CrossRef]

115. Wang, X.; Chen, H.; Fu, X.; Li, S.; Wei, J. A novel antioxidant and ACE inhibitory peptide from rice bran protein: Biochemical characterization and molecular docking study. Lwt 2017, 75, 93-99. [CrossRef]

116. Selamassakul, O.; Laohakunjit, N.; Kerdchoechuen, O.; Yang, L.; Maier, C.S. Isolation and characterisation of antioxidative peptides from bromelain-hydrolysed brown rice protein by proteomic technique. Process Biochem. 2018, 70, 179-187. [CrossRef]

117. Zaky, A.A.; Liu, Y.; Han, P.; Chen, Z.; Jia, Y. Effect of Pepsin-Trypsin In Vitro Gastro-Intestinal Digestion on the Antioxidant Capacities of Ultra-Filtrated Rice Bran Protein Hydrolysates (Molecular Weight $>10 \mathrm{kDa} ; 3-10 \mathrm{kDa}$, and $<3 \mathrm{kDa}$ ). Int. J. Pept. Res. Ther. 2020, 26, 1661-1667. [CrossRef]

118. Pantoa, T.; Kubota, M.; Suwannaporn, P.; Kadowaki, M. Characterization and bioactivities of young rice protein hydrolysates. J. Cereal Sci. 2020, 95, 103049. [CrossRef]

119. Li, H.; Wang, Z.; Liang, M.; Cai, L.; Yang, L. Methionine augments antioxidant activity of rice protein during gastrointestinal digestion. Int. J. Mol. Sci. 2019, 20, 868. [CrossRef]

120. Phongthai, S.; D'Amico, S.; Schoenlechner, R.; Homthawornchoo, W.; Rawdkuen, S. Fractionation and antioxidant properties of rice bran protein hydrolysates stimulated by in vitro gastrointestinal digestion. Food Chem. 2018, 240, 156-164. [CrossRef] [PubMed]

121. Gomes, M.H.G.; Kurozawa, L.E. Improvement of the functional and antioxidant properties of rice protein by enzymatic hydrolysis for the microencapsulation of linseed oil. J. Food Eng. 2020, 267, 109761. [CrossRef]

122. Zhou, K.; Canning, C.; Sun, S. Effects of rice protein hydrolysates prepared by microbial proteases and ultrafiltration on free radicals and meat lipid oxidation. LWT Food Sci. Technol. 2013, 50, 331-335. [CrossRef]

123. Yan, Q.-J.; Huang, L.-H.; Sun, Q.; Jiang, Z.-Q.; Wu, X. Isolation, identification and synthesis of four novel antioxidant peptides from rice residue protein hydrolyzed by multiple proteases. Food Chem. 2015, 179, 290-295. [CrossRef] [PubMed] 
124. Shen, Y.; Hu, R.; Li, Y. Antioxidant and Emulsifying Activities of Corn Gluten Meal Hydrolysates in Oil-in-Water Emulsions. J. Am. Oil Chem. Soc. 2020, 97, 175-185. [CrossRef]

125. Zhang, S.; Zhang, M.; Yang, R.; Zhang, S.; Lin, S. Preparation, identification, and activity evaluation of antioxidant peptides from protein hydrolysate of corn germ meal. J. Food Process. Preserv. 2019, 43, e14160. [CrossRef]

126. Hu, R.; Dunmire, K.M.; Truelock, C.N.; Paulk, C.B.; Aldrich, G.; Li, Y. Antioxidant performances of corn gluten meal and DDGS protein hydrolysates in food, pet food, and feed systems. J. Agric. Food Res. 2020, 2, 100030. [CrossRef]

127. Zhou, K.; Sun, S.; Canning, C. Production and functional characterisation of antioxidative hydrolysates from corn protein via enzymatic hydrolysis and ultrafiltration. Food Chem. 2012, 135, 1192-1197. [CrossRef]

128. Wang, X.-J.; Zheng, X.-Q.; Kopparapu, N.-K.; Cong, W.-S.; Deng, Y.-P.; Sun, X.-J.; Liu, X.-L. Purification and evaluation of a novel antioxidant peptide from corn protein hydrolysate. Process Biochem. 2014, 49, 1562-1569. [CrossRef]

129. Ren, X.; Liang, Q.; Zhang, X.; Hou, T.; Li, S.; Ma, H. Stability and antioxidant activities of corn protein hydrolysates under simulated gastrointestinal digestion. Cereal Chem. 2018, 95, 760-769. [CrossRef]

130. Hu, R.; Chen, G.; Li, Y. Production and Characterization of Antioxidative Hydrolysates and Peptides from Corn Gluten Meal Using Papain, Ficin, and Bromelain. Molecules 2020, 25, 4091. [CrossRef] [PubMed]

131. Xu, S.; Shen, Y.; Li, Y. Antioxidant activities of sorghum kafirin alcalase hydrolysates and membrane/gel filtrated fractions. Antioxidants 2019, 8, 131. [CrossRef] [PubMed]

132. Xu, S.; Shen, Y.; Xu, J.; Qi, G.; Chen, G.; Wang, W.; Sun, X.; Li, Y. Antioxidant and anticancer effects in human hepatocarcinoma (HepG2) cells of papain-hydrolyzed sorghum kafirin hydrolysates. J. Funct. Foods 2019, 58, 374-382. [CrossRef]

133. Xu, S.; Shen, Y.; Chen, G.; Bean, S.; Li, Y. Antioxidant characteristics and identification of peptides from sorghum kafirin hydrolysates. J. Food Sci. 2019, 84, 2065-2076. [CrossRef] [PubMed]

134. Marciniak, A.; Suwal, S.; Naderi, N.; Pouliot, Y.; Doyen, A. Enhancing enzymatic hydrolysis of food proteins and production of bioactive peptides using high hydrostatic pressure technology. Trends Food Sci. Technol. 2018, 80, 187-198. [CrossRef]

135. Wen, C.; Zhang, J.; Zhang, H.; Duan, Y.; Ma, H. Plant protein-derived antioxidant peptides: Isolation, identification, mechanism of action and application in food systems: A review. Trends Food Sci. Technol. 2020, 105, 308-322. [CrossRef]

136. Samaranayaka, A.G.; Li-Chan, E.C. Food-derived peptidic antioxidants: A review of their production, assessment, and potential applications. J. Funct. Foods 2011, 3, 229-254. [CrossRef]

137. Di Bernardini, R.; Rai, D.K.; Bolton, D.; Kerry, J.; O’Neill, E.; Mullen, A.M.; Harnedy, P.; Hayes, M. Isolation, purification and characterization of antioxidant peptidic fractions from a bovine liver sarcoplasmic protein thermolysin hydrolyzate. Peptides 2011, 32, 388-400. [CrossRef] [PubMed]

138. Karami, Z.; Akbari-Adergani, B. Bioactive food derived peptides: A review on correlation between structure of bioactive peptides and their functional properties. J. Food Sci. Technol. 2019, 56, 535-547. [CrossRef]

139. Daliri, E.B.-M.; Lee, B.H.; Oh, D.H. Current trends and perspectives of bioactive peptides. Crit. Rev. Food Sci. Nutr. 2018, 58, 2273-2284. [CrossRef]

140. Gänzle, M.G. Enzymatic and bacterial conversions during sourdough fermentation. Food Microbiol. 2014, 37, 2-10. [CrossRef]

141. Raveschot, C.; Cudennec, B.; Coutte, F.; Flahaut, C.; Fremont, M.; Drider, D.; Dhulster, P. Production of bioactive peptides by Lactobacillus species: From gene to application. Front. Microbiol. 2018, 9, 2354. [CrossRef]

142. Gobbetti, M.; De Angelis, M.; Corsetti, A.; Di Cagno, R. Biochemistry and physiology of sourdough lactic acid bacteria. Trends Food Sci. Technol. 2005, 16, 57-69. [CrossRef]

143. Galli, V.; Mazzoli, L.; Luti, S.; Venturi, M.; Guerrini, S.; Paoli, P.; Vincenzini, M.; Granchi, L.; Pazzagli, L. Effect of selected strains of lactobacilli on the antioxidant and anti-inflammatory properties of sourdough. Int. J. Food Microbiol. 2018, 286, 55-65. [CrossRef] [PubMed]

144. Galli, V.; Venturi, M.; Pini, N.; Guerrini, S.; Granchi, L.; Vincenzini, M. Liquid and firm sourdough fermentation: Microbial robustness and interactions during consecutive backsloppings. LWT 2019, 105, 9-15. [CrossRef]

145. Luti, S.; Mazzoli, L.; Ramazzotti, M.; Galli, V.; Venturi, M.; Marino, G.; Lehmann, M.; Guerrini, S.; Granchi, L.; Paoli, P. Antioxidant and anti-inflammatory properties of sourdoughs containing selected Lactobacilli strains are retained in breads. Food Chem. 2020, 322, 126710. [CrossRef] [PubMed]

146. Wu, J.; Cheng, Y.; Dong, Y. Antioxidant activity of Lactobacillus plantarum DY-1 fermented wheat germ extract and its influence on lipid oxidation and texture properties of emulsified sausages. J. Food Qual. 2020, 2020, 8885886. [CrossRef]

147. Niu, L.-Y.; Jiang, S.-T.; Pan, L.-J. Preparation and evaluation of antioxidant activities of peptides obtained from defatted wheat germ by fermentation. J. Food Sci. Technol. 2013, 50, 53-61. [CrossRef]

148. Wang, K.; Niu, M.; Song, D.; Liu, Y.; Wu, Y.; Zhao, J.; Li, S.; Lu, B. Evaluation of biochemical and antioxidant dynamics during the co-fermentation of dehusked barley with Rhizopus oryzae and Lactobacillus plantarum. J. Food Biochem. 2020, 44, e13106. [CrossRef]

149. Sánchez-López, F.; Robles-Olvera, V.J.; Hidalgo-Morales, M.; Tsopmo, A. Characterization of Amaranthus hypochondriacus seed protein fractions, and their antioxidant activity after hydrolysis with lactic acid bacteria. J. Cereal Sci. 2020, 95, 103075. [CrossRef]

150. Li-Chan, E.C. Bioactive peptides and protein hydrolysates: Research trends and challenges for application as nutraceuticals and functional food ingredients. Curr. Opin. Food Sci. 2015, 1, 28-37. [CrossRef]

151. Tu, M.; Cheng, S.; Lu, W.; Du, M. Advancement and prospects of bioinformatics analysis for studying bioactive peptides from food-derived protein: Sequence, structure, and functions. Trac Trends Anal. Chem. 2018, 105, 7-17. [CrossRef] 
152. Agyei, D.; Pan, S.; Acquah, C.; Bekhit, A.E.D.A.; Danquah, M.K. Structure-informed detection and quantification of peptides in food and biological fluids. J. Food Biochem. 2019, 43, e12482. [CrossRef] [PubMed]

153. Nongonierma, A.B.; Mazzocchi, C.; Paolella, S.; FitzGerald, R.J. Release of dipeptidyl peptidase IV (DPP-IV) inhibitory peptides from milk protein isolate (MPI) during enzymatic hydrolysis. Food Res. Int. 2017, 94, 79-89. [CrossRef]

154. Guedes, I.A.; de Magalhães, C.S.; Dardenne, L.E. Receptor-ligand molecular docking. Biophys. Rev. 2014, 6, 75-87. [CrossRef]

155. Yap, P.G.; Gan, C.Y. In vivo challenges of anti-diabetic peptide therapeutics: Gastrointestinal stability, toxicity and allergenicity. Trends Food Sci. Technol. 2020, 105, 161-175. [CrossRef]

156. Nongonierma, A.B.; FitzGerald, R.J. Learnings from quantitative structure-activity relationship (QSAR) studies with respect to food protein-derived bioactive peptides: A review. RSC Adv. 2016, 6, 75400-75413. [CrossRef]

157. Guo, H.; Wang, Y.; He, Q.; Zhang, Y.; Hu, Y.; Wang, Y.; Lin, Z. In silico rational design and virtual screening of antixoidant tripeptides based on 3D-QSAR modeling. J. Mol. Struct. 2019, 1193, 223-230. [CrossRef]

158. Yan, W.; Lin, G.; Zhang, R.; Liang, Z.; Wu, W. Studies on the bioactivities and molecular mechanism of antioxidant peptides by 3D-QSAR, in vitro evaluation and molecular dynamic simulations. Food Funct. 2020, 11, 3043-3052. [CrossRef]

159. Bermúdez-Aguirre, D.; Barbosa-Cánovas, G.V. An update on high hydrostatic pressure, from the laboratory to industrial applications. Food Eng. Rev. 2011, 3, 44-61. [CrossRef]

160. Bonomi, F.; Fiocchi, A.; Frøkiær, H.; Gaiaschi, A.; Iametti, S.; Poiesi, C.; Rasmussen, P.; Restani, P.; Rovere, P. Reduction of immunoreactivity of bovine [Beta]-lactoglobulin upon combined physical and proteolytic treatment. J. Dairy Res. 2003, 70, 51. [CrossRef] [PubMed]

161. Chemat, F.; Rombaut, N.; Sicaire, A.-G.; Meullemiestre, A.; Fabiano-Tixier, A.-S.; Abert-Vian, M. Ultrasound assisted extraction of food and natural products. Mechanisms, techniques, combinations, protocols and applications. A review. Ultrason. Sonochem. 2017, 34, 540-560. [CrossRef]

162. Sullivan, A.C.; Pangloli, P.; Dia, V.P. Impact of ultrasonication on the physicochemical properties of sorghum kafirin and in vitro pepsin-pancreatin digestibility of sorghum gluten-like flour. Food Chem. 2018, 240, 1121-1130. [CrossRef] [PubMed]

163. Kuan, Y.-H.; Bhat, R.; Patras, A.; Karim, A.A. Radiation processing of food proteins-A review on the recent developments. Trends Food Sci. Technol. 2013, 30, 105-120. [CrossRef]

164. Wang, L.; Li, T.; Sun, D.; Tang, M.; Sun, Z.; Chen, L.; Luo, X.; Li, Y.; Wang, R.; Li, Y. Effect of electron beam irradiation on the functional properties and antioxidant activity of wheat germ protein hydrolysates. Innov. Food Sci. Emerg. Technol. 2019, 54, 192-199. [CrossRef]

165. Li, T.; Wang, L.; Sun, D.; Li, Y.; Chen, Z. Effect of enzymolysis-assisted electron beam irradiation on structural characteristics and antioxidant activity of rice protein. J. Cereal Sci. 2019, 89, 102789. [CrossRef]

166. Liu, F.; Chen, Z.; Shao, J.; Wang, C.; Zhan, C. Effect of fermentation on the peptide content, phenolics and antioxidant activity of defatted wheat germ. Food Biosci. 2017, 20, 141-148. [CrossRef]

167. Babini, E.; Tagliazucchi, D.; Martini, S.; Dei Più, L.; Gianotti, A. LC-ESI-QTOF-MS identification of novel antioxidant peptides obtained by enzymatic and microbial hydrolysis of vegetable proteins. Food Chem. 2017, 228, 186-196. [CrossRef] [PubMed]

168. Zhang, J.; Wen, C.; Li, C.; Duan, Y.; Zhang, H.; Ma, H. Antioxidant Peptide Fractions Isolated from Wheat Germ Protein with Subcritical Water Extraction and Its Transport Across Caco-2 Cells. J. Food Sci. 2019, 84, 2139-2146. [CrossRef]

169. Chen, M.-L.; Ning, P.; Jiao, Y.; Xu, Z.; Cheng, Y.-H. Extraction of antioxidant peptides from rice dreg protein hydrolysate via an angling method. Food Chem. 2021, 337, 128069. [CrossRef]

170. Liang, Q.; Ren, X.; Ma, H.; Li, S.; Xu, K.; Oladejo, A.O. Effect of low-frequency ultrasonic-assisted enzymolysis on the physicochemical and antioxidant properties of corn protein hydrolysates. J. Food Qual. 2017, 2017, 2784146. [CrossRef]

171. Huang, D.; Ou, B.; Prior, R.L. The chemistry behind antioxidant capacity assays. J. Agric. Food Chem. 2005, 53, 1841-1856. [CrossRef]

172. Wang, F.; Weng, Z.; Lyu, Y.; Bao, Y.; Liu, J.; Zhang, Y.; Sui, X.; Fang, Y.; Tang, X.; Shen, X. Wheat germ-derived peptide ADWGGPLPH abolishes high glucose-induced oxidative stress via modulation of the PKC $\zeta /$ AMPK/NOX4 pathway. Food Funct. 2020, 11, 6843-6854. [CrossRef] [PubMed]

173. Itoh, K.; Tong, K.I.; Yamamoto, M. Molecular mechanism activating Nrf2-Keap1 pathway in regulation of adaptive response to electrophiles. Free Radic. Biol. Med. 2004, 36, 1208-1213. [CrossRef]

174. Kobayashi, M.; Yamamoto, M. Nrf2-Keap1 regulation of cellular defense mechanisms against electrophiles and reactive oxygen species. Adv. Enzym. Regul. 2006, 46, 113-140. [CrossRef] [PubMed]

175. Moritani, C.; Kawakami, K.; Shimoda, H.; Hatanaka, T.; Suzaki, E.; Tsuboi, S. Protective Effects of Rice Peptide Oryza Peptide-P60 against Oxidative Injury through Activation of Nrf2 Signaling Pathway In Vitro and In Vivo. ACS Omega 2020, 5, 13096-13107. [CrossRef] [PubMed]

176. Sullivan, A.C.; Pangloli, P.; Dia, V.P. Kafirin from Sorghum bicolor inhibition of inflammation in THP-1 human macrophages is associated with reduction of intracellular reactive oxygen species. Food Chem. Toxicol. 2018, 111, 503-510. [CrossRef] [PubMed]

177. Liang, Y.; Lin, Q.; Huang, P.; Wang, Y.; Li, J.; Zhang, L.; Cao, J. Rice bioactive peptide binding with $\mathrm{TLR}_{4}$ to overcome $\mathrm{H}_{2} \mathrm{O}_{2}{ }^{-}$ induced injury in human umbilical vein endothelial cells through NF-kB signaling. J. Agric. Food Chem. 2018, 66, 440-448. [CrossRef] 
178. Cruz-Chamorro, I.; Álvarez-Sánchez, N.; Santos-Sánchez, G.; Pedroche, J.; Fernández-Pachón, M.-S.; Millán, F.; Millán-Linares, M.C.; Lardone, P.J.; Bejarano, I.; Guerrero, J.M. Immunomodulatory and antioxidant properties of wheat gluten protein hydrolysates in human peripheral blood mononuclear cells. Nutrients 2020, 12, 1673. [CrossRef] [PubMed]

179. Ji, Z.; Mao, J.; Chen, S.; Mao, J. Antioxidant and anti-inflammatory activity of peptides from foxtail millet (Setaria italica) prolamins in HaCaT cells and RAW264. 7 murine macrophages. Food Biosci. 2020, 36, 100636. [CrossRef]

180. Wang, L.; Ding, L.; Xue, C.; Ma, S.; Du, Z.; Zhang, T.; Liu, J. Corn gluten hydrolysate regulates the expressions of antioxidant defense and ROS metabolism relevant genes in $\mathrm{H}_{2} \mathrm{O}_{2}$-induced HepG2 cells. J. Funct. Foods 2018, 42, 362-370. [CrossRef]

181. Reagan-Shaw, S.; Nihal, M.; Ahmad, N. Dose translation from animal to human studies revisited. FASEB J. 2008, $22,659-661$. [CrossRef]

182. Chen, S.; Lin, D.; Gao, Y.; Cao, X.; Shen, X. A novel antioxidant peptide derived from wheat germ prevents high glucose-induced oxidative stress in vascular smooth muscle cells in vitro. Food Funct. 2017, 8, 142-150. [CrossRef] [PubMed]

183. Díaz-Gómez, J.L.; Ortíz-Martínez, M.; Aguilar, O.; García-Lara, S.; Castorena-Torres, F. Antioxidant activity of zein hydrolysates from Zea species and their cytotoxic effects in a hepatic cell culture. Molecules 2018, 23, 312. [CrossRef] [PubMed]

184. Kawaguchi, T.; Ueno, T.; Nogata, Y.; Hayakawa, M.; Koga, H.; Torimura, T. Wheat-bran autolytic peptides containing a branched-chain amino acid attenuate non-alcoholic steatohepatitis via the suppression of oxidative stress and the upregulation of AMPK/ACC in high-fat diet-fed mice. Int. J. Mol. Med. 2017, 39, 407-414. [CrossRef]

185. Jiang, X.; Cui, Z.; Wang, L.; Xu, H.; Zhang, Y. Production of bioactive peptides from corn gluten meal by solid-state fermentation with Bacillus subtilis MTCC5480 and evaluation of its antioxidant capacity in vivo. LWT 2020, 131, 109767. [CrossRef]

186. Yu, Y.; Wang, L.; Wang, Y.; Lin, D.; Liu, J. Hepatoprotective effect of albumin peptides from corn germ meal on chronic alcohol-induced liver injury in mice. J. Food Sci. 2017, 82, 2997-3004. [CrossRef] 